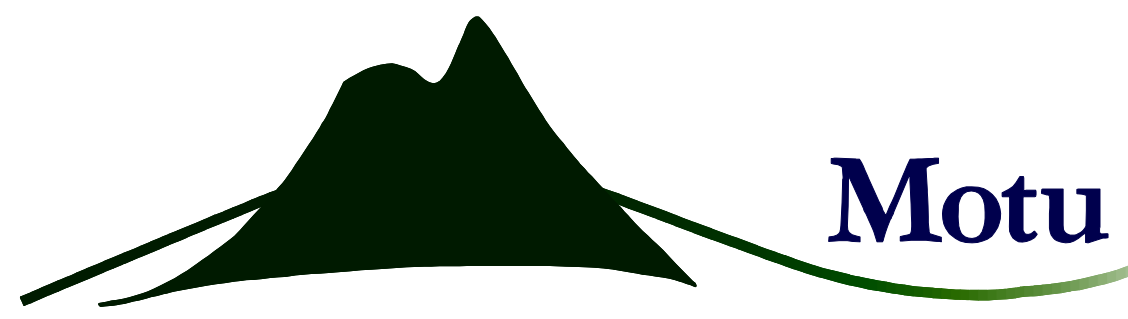

Predicting harvestability of existing

Pinus radiata stands: 2013-2030

projections of stumpage profits from

pre-90 and post-89 forests

Matt Thirkettle and Suzi Kerr

Working Paper 15-16

September 2015 


\section{Author contact details}

Matt Thirkettle

Motu Economic and Public Policy Research

mkt68@cornell.edu

Suzi Kerr

Motu Economic and Public Policy Research

suzi.kerr@motu.org.nz

\section{Acknowledgements}

We thank the Ministry for Primary Industries for funding this project. We thank James McDevitt (MPI), Gerard Horgan (MPI), and Ivan Luketina (AgriFax) for their helpful feedback and advice. Thanks also to Corey Allan (Motu) for technical assistance. Any remaining errors and omissions are the responsibility of the authors.

\section{Disclaimer}

This report was prepared by Motu on behalf of the Ministry for Primary Industries. The Ministry does not accept any responsibility or liability for error of fact, omission, interpretation or opinion that may be present, nor for the consequences of any decisions based on this information. Any view or opinion expressed does not necessarily represent the view of the Ministry for Primary Industries.

\section{Motu Economic and Public Policy Research}

PO Box 24390

Wellington

New Zealand

Email_info@motu.org.nz

Telephone +6449394250

Website www.motu.org.nz

(C) 2014 Motu Economic and Public Policy Research Trust and the authors. Short extracts, not exceeding two paragraphs, may be quoted provided clear attribution is given. Motu Working Papers are research materials circulated by their authors for purposes of information and discussion. They have not necessarily undergone formal peer review or editorial treatment. ISSN 1176-2667 (Print), ISSN 1177-9047 (Online). 


\begin{abstract}
Our goal is to predict which forests are harvestable in New Zealand each year, and the stumpage profits attained from harvesting. We begin by documenting how Motu updates the 2008 Land Use in Rural New Zealand map to match the 2013 National Exotic Forest Description planted forest dataset. We then produce forest stand maps for the years 2013-2030. Last, we describe how we assign stumpage profits, and the distribution of stumpage profits over the simulation years (2013-2030). We find that stumpage profits are: always positive; increasing through time (2013-2030); lowest (on average) in the West Coast; and highest (on average) in the North Island East Coast. Our results suggest that forest owners will always harvest given that they have already incurred planting and growing costs. Limitations in data, including the need to use averages of yields and some costs across wide areas, and the effect of market conditions, and their role in determining the pace and average age at which the estate is harvested, mean that the true distribution of stumpage profits is likely to be wider. Those most likely to not harvest would be those with low estimated stumpage.
\end{abstract}

\title{
JEL codes
}

Q23, Q55

\section{Keywords}

Forestry, New Zealand, land use, stumpage profits, harvesting 


\section{Contents}

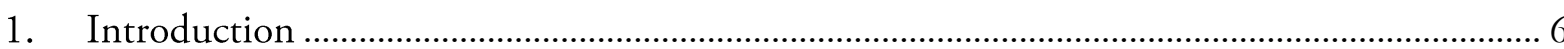

2. Create a 2013 forest map that matches areas of forest by territory authority (TA) to the 2013 NEFD planted forest dataset

3. Identify and adjust pre- 90 and post- 89 forest stands to match the NEFD areas by TA and forest type.

4. Adjust the 2013 age-class distribution in each TA for each forest type to match NEFD

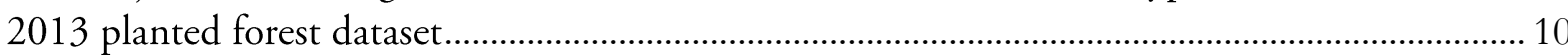

5. Predict potentially harvestable forest and assign harvest rates................................................... 11

6. Estimate stumpage profit for each pixel in each year under the assumptions: (1) it is a pruned forest stand; and (2) it is an unpruned forest stand ............................................................ 15

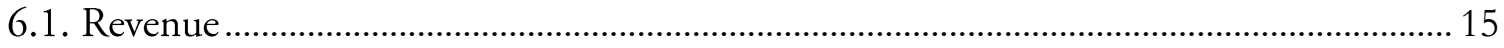

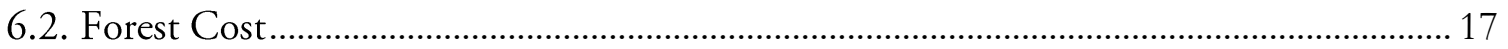

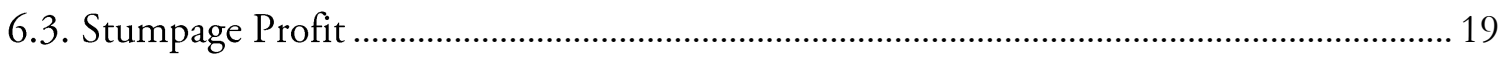

7. Assign a pruning regime for each pixel (either pruned or not pruned) .................................. 19

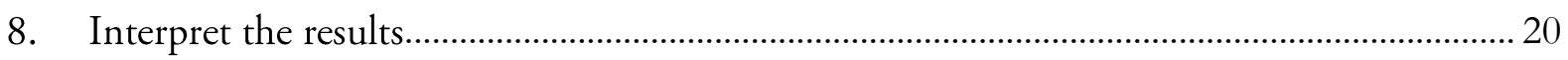

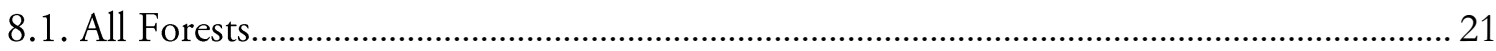

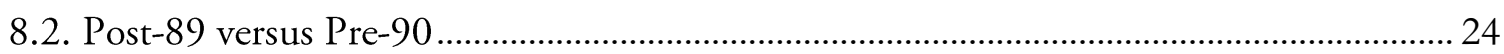

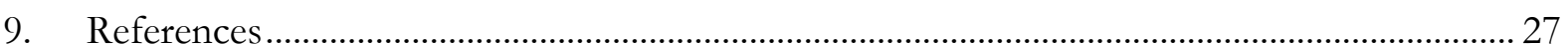

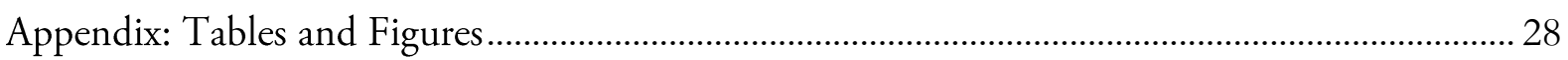

\section{Tables}

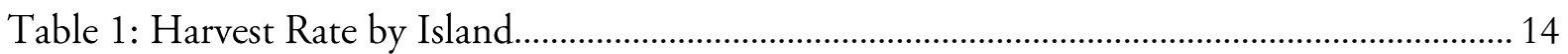

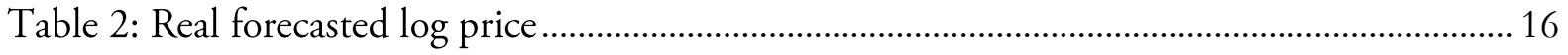

Table 3: Forecast real stumpage prices by type (pruned, unpruned, pulp) ……….......................... 17

Table 4: Harvest cost (\$ per tonne) .................................................................................................... 18

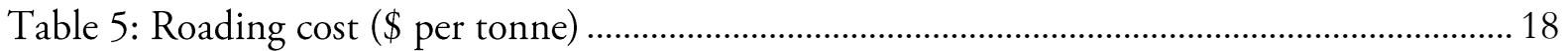

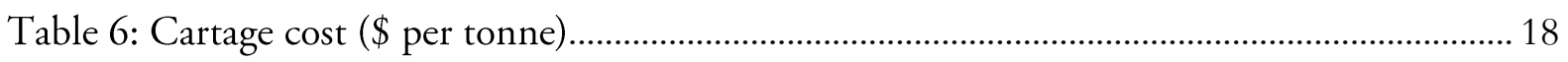

Table 7: Proportion of Pruned and Unpruned Planted Forest by WSR (2013)............................. 20

Table 8 Mean expected forest profit by WSR for land in radiata pine in 2013 .............................. 26

Table 9: Compare Area for the 2013 LURNZ and NEFD Dataset ................................................. 28 
Table 10: Average Stumpage Profit by Year and WSR for All Planted Forest (\$/ha) ..................... 31

Table 11: Average Stumpage Profit by Year and WSR for Pre-90 Planted Forest ( $\$ /$ ha) ............. 33

Table 12: Average Stumpage Profit by Year and WSR for Post-89 Planted Forest ( $\$ /$ ha) ............ 35

\section{Figures}

Figure 1: Total planting by age class.

Figure 2: Average Stumpage Profit over 2013-2030 by Wood Supply Region for All Planted

Forest

Figure 3: Average Stumpage Profit over Wood Supply Regions by Year for All Planted Forest .. 22

Figure 4: Histogram of Stumpage Profit for 2013 for All Planted Forest........................................ 23

Figure 5: Histogram of Stumpage Profit for 2030 for All Planted Forest......................................... 23

Figure 6: Stumpage Profit Map for 2013 for All Planted Forest (\$/ha) ........................................... 37

Figure 7: Stumpage Profit Map for 2030 for All Planted Forest $(\$ /$ ha $)$............................................ 38

Figure 8: Average Stumpage Profit over 2013-2030 by Wood Supply Region by Forest Type... 39

Figure 9: Average Stumpage Profit over Wood Supply Region by Year by Forest Type............... 40

Figure 10: Histogram of Stumpage Profit for 2030 for Pre-90 Forest .............................................. 41

Figure 11: Histogram of Stumpage Profit for 2030 for Post-89 Forest ............................................. 42

Figure 12: Stumpage Profit Map for 2030 for Pre-90 Forest (\$/ha) .................................................. 43

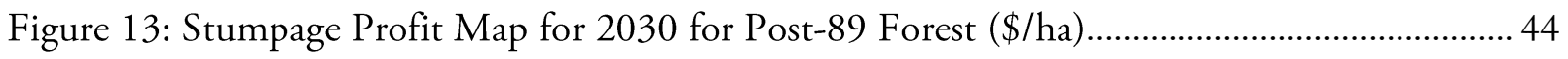

Figure 14: NPV Map for 2013 Pre-90 Forest (\$/ha) - 7\% discount rate........................................ 45

Figure 15: NPV Map for 2013 Post-89 Forest (\$/ha) - 7 \% discount rate..................................... 46

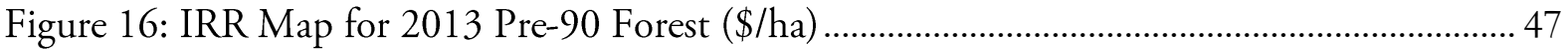

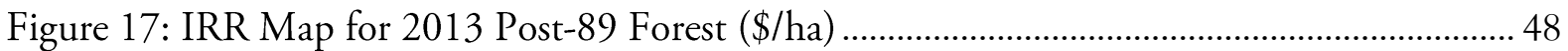




\section{Introduction}

Our goal is to predict which forests are harvestable each year in New Zealand in terms of age, and the stumpage profits likely to be attained from harvesting, in order to gain insight into the likelihood that some forests will not be harvested, with implications for New Zealand's net greenhouse gas emissions and United Nations Framework Convention on Climate Change reporting.

For the years 2014-2030 we use Motu's Land Use in Rural New Zealand (LURNZ) program to simulate the forest stands (at a 25 hectare resolution) that are likely to be harvested. ${ }^{1}$ Next, we calculate stumpage profits for each forest pixel, which can vary by, among other things, when the forest is first planted (either prior to 1990 (pre-90) or after 1989 (post-89)). We aggregate stumpage profits to the wood supply region (WSR) level for each forest type (either pre-90 or post-89). We also plot the stumpage profit distribution by year (2013-2030), where 2013 is the base year. Last, we produce 2013 net present value (NPV) and internal rate of return (IRR) on existing radiata forest in the form of a table by wood supply region and maps. These are an updated version of the results produced in Olssen et al. (2012). The 2013 maps take into account price changes documented here.

We find that stumpage profits are always positive. This would suggest that forest owners will always harvest. Limitations in data, however, including the need to use averages of yields and some costs across wide areas, and the effect of market conditions, and their role in determining the pace and average age at which the estate is harvested, mean that the true distribution of stumpage profits is likely to be wider than our estimates. Those most likely to actually face negative stumpage and hence not harvest would be those with low, but positive, estimated stumpage. The West Coast region in 2013 is projected to receive the lowest average stumpage profit over all WSRs and simulation years $(\$ 11,224 / \mathrm{ha})$ and the North Island East Coast region in 2027 is projected to receive the highest average stumpage profit over all WSRs and simulation years $(\$ 41,680 / \mathrm{ha}){ }^{2}$ In 2013 , the estimated stumpage profits range from around

\footnotetext{
${ }^{1}$ For code, other documentation, and access to data for research purposes go to http://www.motu.org.nz/ourwork/environment-and-resources/lurnz/.

2 All reported values are measured in 2013 dollars.
} 
$\$ 6,000$ per ha up to over $\$ 50,000$. Varying cost and yield data explains the variation in stumpage profits over WSRs. The West Coast typically has steeper land that is far from a port or mill, which both increase stumpage cost. Forest stands also have low yield rates in the West Coast due to poor weather conditions (trees grow slowly and produce poor quality timber in wet regions). On the other hand, the weather in North Island East Coast is dry and warm, which both contribute to higher yield rates. The land is typically flat there as well, so that harvest costs are relatively cheaper (on average) in the North Island East Coast.

Average stumpage profit over all WSRs is projected to increase from \$25,554/ha in 2013 to $\$ 32,151 /$ ha in 2030 . The increasing proportion of post-89 forest stands is driving this time trend, as these typically have higher yields than pre-90 forest stands.

Key Steps:

1. Create a 2013 forest map that matches areas of forest by territory authority (TA) to the 2013 NEFD planted forest dataset.

2. Identify and adjust pre- 90 and post- 89 forest stands to match the NEFD areas by TA and forest type.

3. Adjust the 2013 age-class distribution in each TA for each forest type to match the NEFD 2013 planted forest dataset.

4. Predict potentially harvestable forest and assign harvest regimes. ${ }^{3}$

5. Estimate stumpage profit for each pixel in each year under the assumptions: (1) it is a pruned forest stand; and (2) it is an unpruned forest stand.

6. Assign a pruning regime for each pixel (either pruned or not pruned) and assign stumpage profits accordingly.

7. Interpret the results.

\section{Create a 2013 forest map that matches areas of forest by territory authority (TA) to the 2013 NEFD planted forest dataset}

We use Motu's LURNZ model to simulate a 2013 forest map of New Zealand. LURNZ is a partial equilibrium model that is currently set up to simulate changes in private dairy, sheepbeef, plantation forestry, and scrub land uses over time and space. The model uses the 25 ha

\footnotetext{
${ }^{3}$ Harvestable forest is defined to be Pinus radiata between the age of 26 and 40 (inclusive), as described in Section 0.
} 
2008 LUCAS map to determine where forest stands are located in New Zealand in 2008. Then LURNZ simulates and allocates national-level land-use change to produce a 2013 forest map. ${ }^{4}$

We compare LURNZ's simulated 2013 forest map to the 2013 National Exotic Forest Description (NEFD) dataset for planted exotic forest stands in New Zealand. ${ }^{5}$ This NEFD dataset reports the number of hectares in 2013 of exotic forest stands planted by TA, age class, and forest type (forest that was planted before 1990 (pre-90) or forest on land that changed land use to forestry post 1989 (post-89)). ${ }^{6}$

The area of forests planted at the TA level in the 2013 LURNZ map does not match the NEFD planted forest dataset. We assume the NEFD dataset is more accurate than our LURNZ map, so we adjust our LURNZ map accordingly. In particular, we assume that the LUCAS 2008 map used in the LURNZ model incorrectly assigned land between forest and scrub (scrub is land naturally reverting to native forest). So, if adjustments are needed in our LURNZ map, we reassign forest to scrub or vice versa. For a given TA, if LURNZ reports more forest area than the NEFD dataset, we reassign forest stands in our map to scrub land. The land that is assigned to forest that is least suited for forest (as measured by forest pixel ranking) are likely to be scrub. ${ }^{7,8}$ In this TA, we convert LURNZ - NEFD pixels of the poorest quality forest to scrub. On the other hand, for a given TA, if LURNZ reports less forest than the NEFD dataset, then we reassign pixels of scrubland to forest (we select the best quality land for forest in this case).?

Table 9 in Appendix 1 reports the absolute and relative difference between the 2013 NEFD planted forest dataset and the 2013 LURNZ simulated map. ${ }^{10}$ Absolute differences are in

\footnotetext{
${ }^{4}$ The spatial allocation of land in LURNZ is documented and validated in (Anastasiadis et al. 2014).

${ }^{5}$ Exotic forest stands include Pinus radiata (radiata pine), Pseudotsuga menziesii (Douglas-fir or Oregon pine), and other exotic forest species. Of the total area of exotic forests planted in the NEFD dataset, $89.9 \%$ is radiata pine, $6.2 \%$ is Douglas-fir, and $3.9 \%$ is other exotic forest species (categorized as cypress, softwoods, eucalyptus, hardwoods) (Ministry for Primary Industries, 2013b).

${ }^{6}$ The NEFD planted dataset is restricted and provided to Motu by MPI. The Motu data library reference is R10080.

${ }^{7}$ Poor quality land tends to be steep, far from a port or mill, far from nearest town, and have a poor land-use capability (LUC) rating.

${ }^{8}$ Each pixel is assigned a ranking number from zero to one for each land-use type (dairy, sheep/beef, scrub, and forestry. A pixel with a ranking close to one for, say, dairy is better suited for dairy land than a pixel with a dairy ranking close to zero. Ranking is determined by a logit model using coefficients estimated by Timar (2011). Moreover, for a given pixel the pixel ranking for each land-use type sums to one.

${ }^{9}$ If we run out of scrub land, then we covert the poorest quality sheep and beef land to forest. If we also run out of sheep and beef land, then we convert the poorest quality dairy land to forest.

${ }^{10}$ Differences between LURNZ and NEFD can be attributed to measurement error in each dataset. LURNZ produces a simulated map building on the 2008 LUCAS map; it is subject to simulation error within the LURNZ algorithm and remote sensing error in the LUCAS map. For the 2013 NEFD data was collected from a
} 
hectares and relative differences are in percent. The NEFD dataset has 296,500ha (or 17\%) more plantation forests than the 2013 LURNZ map. The NEFD dataset has more forest than LURNZ in 36 TAs, has less forest in 33 TAs, and the same in 1 TA. The largest differences between NEFD and LURNZ (in magnitude) occurs in Whakatane (58,000ha), Taupo $(57,500 \mathrm{ha})$, and Gisborne $(35,000 \mathrm{ha}) .{ }^{11}$ There is also a large relative difference between the two datasets in: Whakatane (56\%), lower forest areas Queenstown-Lake District (73\%) and Christchurch (77\%) as well as some areas with very small amounts of forest. ${ }^{12}$ After our adjustments, the area of exotic forest in LURNZ matches that in NEFD in every Territorial Authority; we henceforth assume that this forest is all Pinus radiata. ${ }^{13}$

\section{Identify and adjust pre-90 and post-89 forest stands to match the NEFD areas by TA and forest type}

For each pixel in the LURNZ map we assign an indicator variable for pre-90 and post-89 forest types using the forest stand's age and the LUCAS map: All forest stands older than 24 are classified as pre-90; forest stands with LUCAS ID $=71$ or 72 are classified as pre-90; stands with LUCAS ID $=73$ are classified as post-89; remaining stands are temporarily classified as unassigned. ${ }^{14}$

questionnaire sent to all known forest owners and managers with more than 1000 hectares of forest combined with imputed data on smaller forest owners from the 2012 NEFD. These data were supplemented by 2004 data from AgriQuality Small Forest Grower Surveys. Imputation error (leading to a small overstatement of areas in the older age classes), inaccurate reporting by forest owners and sampling error contribute to the measurement error in the NEFD dataset.

11 The largest relative differences occur in the Franklin District. LURNZ reports 6,950 ha and NEFD reports 43 ha giving a $-16,000 \%$ difference. Franklin was divided between the Waikato and Auckland City district in $2010 .{ }^{11}$ The 2011 NEFD report (MAF, 2012) reported 5,990ha of Pinus radiata in the Franklin District. So the 2013 NEFD dataset incorrectly defines the Franklin District. The ungated versions of the 2011 and 2012 NEFD datasets do not report the Franklin District. We suspect that the inclusion of the Franklin District in the 2013 NEFD was a mistake.

12 To calculate the 'relative error' we calculate the percentage error using each of the datasets in turn as the base, then take the minimum of the absolute value of the percentage errors. This minimises the influence of the choice of base dataset.

${ }^{13}$ Henceforth we assume that all forest reported in the NEFD dataset and in maps that we generate are radiata pine. This assumption is motivated by data limitations (the NEFD dataset does not separately report radiata pine and other exotic forest stands), the similarity between radiata pine and Douglas-fir, and the prominence of radiata pine in New Zealand. The NEFD 2013 (Ministry for Primary Industries, 2013b) reports total planted forest by species. The difference between forest stands in the NEFD dataset and radiata pine in NEFD 2013 is 159,118 ha, suggesting that we over-report radiata pine by $9.3 \%$.

${ }^{14}$ The age of a forest stand in 2008 is determined by Zhang and Kerr (2011). The LURNZ algorithm aged the stands appropriately when creating the 2013 basemap. In our 2013 base map, each pixel has a corresponding age: 
We adjust pre-90 and post- 89 forests to match the NEFD planted forest dataset at the TA-level. We start with post-89 stands. For each TA:

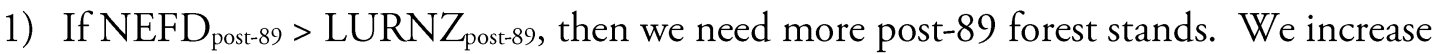
post-89 forest by reassigning pixels in the following order:

a. Unassigned pixels with forest age $\leq 24$;

b. Pre-90 pixels with forest age $\leq 24 ; ;^{15}$

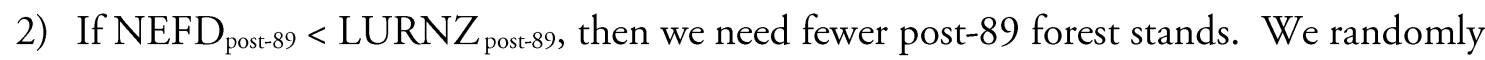
reassign $L U R N Z_{\text {post-89 }}-\mathrm{NEFD}_{\text {post-89 }}$ pixels to pre-90 pixels.

3) Remaining unassigned pixels are reassigned to pre-90 forest.

By construction the NEFD and LURNZ planted forest areas now match at the TA-level by forest type (pre-90 and post-89).

\section{Adjust the 2013 age-class distribution in each TA for each forest type to match NEFD 2013 planted forest dataset}

Our LURNZ map has some forest pixels with an unassigned age (sheep and beef pixels that were changed to forest in Step 1, for example). Also, in our map the number of forest pixels with a particular age may not match the NEFD planting dataset at the TA level. We construct an algorithm so that our map agrees with the NEFD planted forest dataset while minimizing absolute changes in age.

either unassigned or $0-80$. Forest pixels with age $=0$ are blocks awaiting replanting. We assign these pixels age $=1$. Moreover, forests with age greater than 40 are deemed unharvestable. So pixels with age $>40$ are reassigned to age $=41$.

${ }^{15}$ If there are insufficient pixels in a step, then all pixels at that step are renamed post- 89 and the remaining pixels to be allocated are pulled from following steps. If there are sufficient pixels in a step, then a random number generator is used to reassign the required number of pixels as post-89. 
We start with post- 89 forest pixels (order does not matter). We then consider pixels with age=j, $j=1, \ldots 40$ and $T A=k, k=1, \ldots 71:^{16}$

1. If there are too many forest pixels with age $=\mathbf{j}$, we randomly age $L U R N Z_{\text {post- }-89 j, \mathrm{k}}-$ NEFD ${ }_{\text {post-89,j,k }}$ pixels to age $=\mathrm{j}+1$.

2. If there are too few forest pixels with age $=\mathrm{j}$, then we reassign $N E F D_{\text {post- } 89, \mathrm{x}, \mathrm{k}}-\mathrm{LURNZ}_{\text {post- }}$ ${ }_{89, x, \mathrm{k}}$ forest pixels to age $=\mathrm{j}$ (where LURNZ post-89,x,k $_{\text {p }} \in$ fforest stands : post-89 stand in $\mathrm{TA}=\mathrm{k}$ and $x$ indicates either an unassigned pixels or a pixel with age $>j\})$ in the following order:

a. Pixels with unassigned age class

b. Pixels with

$$
\begin{array}{ll}
- & \text { age }=j+1 ; \\
- & \text { age }=j+2 ; \\
\cdots & \\
- & \text { age }=41 .{ }^{17}
\end{array}
$$

We repeat the above algorithm for pre-90 forest stands.

Now our base map and NEFD planted forest dataset agree at the TA-level by forest type for each age class. In other words, our LURNZ map agrees with the NEFD dataset in all respects, and we are ready to assign harvesting regimes as well as calculate stumpage profits.

\section{Predict potentially harvestable forest and assign harvest rates}

Forest stands tend to be harvested between ages 26 and 40 - on average, $28 .{ }^{18}$ Once a forestry stand reaches age 41 it is too large to send to the mill and specialized equipment is needed to harvest (larger grapple yarders, trucks, and skidders are needed). It therefore becomes too expensive to harvest trees 41 years or older. On the other hand, forest stands aged less than 26 are too immature: the wood is not suitable for construction and the tree produces insufficient

\footnotetext{
${ }^{16}$ It is important to start with age $=1$, then move to age $=2, \ldots$ then move to 40 to minimize changes made. Order of TA does not matter.

17 If there is insufficient forest area in a step (say the first step), then the age of all unassigned pixels is set to $j$ and the remaining forest area to be allocated age $=j$ is settled in the following steps. On the other hand, if there is sufficient forest area in a step (say the first step), then a random number generator is used to allocate NEFD LURNZ unassigned pixels as age $=\mathrm{j}$.

18 The average age of harvest is 27.7 years (Ministry for Primary Industries, 2013b).
} 
wood product. As a result, immature forest stands generally do not produce sufficient levels of profit. Therefore only forest stands with age between 26 and 40 are considered harvestable. ${ }^{19}$

Definition: A forest stand is harvestable if and only if its age is between 26 and 40 (inclusive). ${ }^{20}$

Each year we select a proportion of harvestable forest stands to be harvested. The proportion depends on the age of the forest stand. One could imagine that a forest stand aged 26 is less likely to be harvested than one aged 27 , as stands aged 27 are more mature but not too big to make it infeasible to harvest. We use total planted forest by age class to determine harvest rates.

Figure 1 illustrates total planted Pinus radiata by age class in New Zealand in 2013. Stands aged 26 and above diminish to zero, consistent with harvest age above 26 . There is a large spike in forest stands with age between 13 and 19; trees that were planted during the ' 90 s planting boom. Ideally we would observe these data consistently for several years and could estimate the hazard rate - the probability of a forest stand being cleared at a given age, given that it had not been cleared previously. Because we cannot, we assume that the number of trees planted (and replanted) each year between 26 and 40 years ago was roughly consistent so that changes across age classes indicate harvesting.

To reduce the effect of historical variation in planting rates across years we compute the average of planted forest for trees aged 1 to 25 in to get a proxy for total planted trees before forests are harvested. We further smooth the planted stand proxy by taking a 3-period centred moving average. The proxy for each age class is determined as follows:

$$
\begin{gathered}
\text { Proxy }_{\text {age }=25}=\frac{\text { Forest }_{\text {age }}=26}{3}+\frac{2}{3} \cdot \frac{1}{25} \sum_{i=1}^{25} \text { Forest }_{\text {age }=i} \\
\text { Proxy }_{\text {age }=26}=\frac{\text { Forest }_{\text {age }=27}+\text { Forest }_{\text {age }=26}}{3}+\frac{1}{3} \cdot \frac{1}{25} \sum_{i=1}^{25} \text { Forest }_{\text {age }=i} \\
\text { Proxy }_{\text {age }=i \geq 27}=\frac{\text { Forest }_{\text {age }=i+1}+\text { Forest }_{\mathrm{age}=i}+\text { Forest }_{\mathrm{age}=i-1}}{3} .
\end{gathered}
$$

\footnotetext{
19 This does not imply that all forests between age 26 and 40 will be harvested.

20 This definition is motivated by expert advice from Gerard Horgan.
} 
The proxy is constant up to age 26 , and decreasing thereafter, which is driven by our assumption that forestry begins to be harvested at age 26. The proxy is also monotonically decreasing, which is a sufficient condition to get non-negative harvest rates. We use the proxy to estimate the harvesting rate for trees aged 26 to 40 :

$$
\text { Harvest } \text { rate }_{\text {age }=i} \approx \frac{\text { Proxy }_{\text {age }=i-1}-\text { Proxy }_{\text {age }=i}}{\operatorname{Proxy}_{\text {age }=i-1}} \text {. }
$$

\section{Figure 1: Total planting by age class}

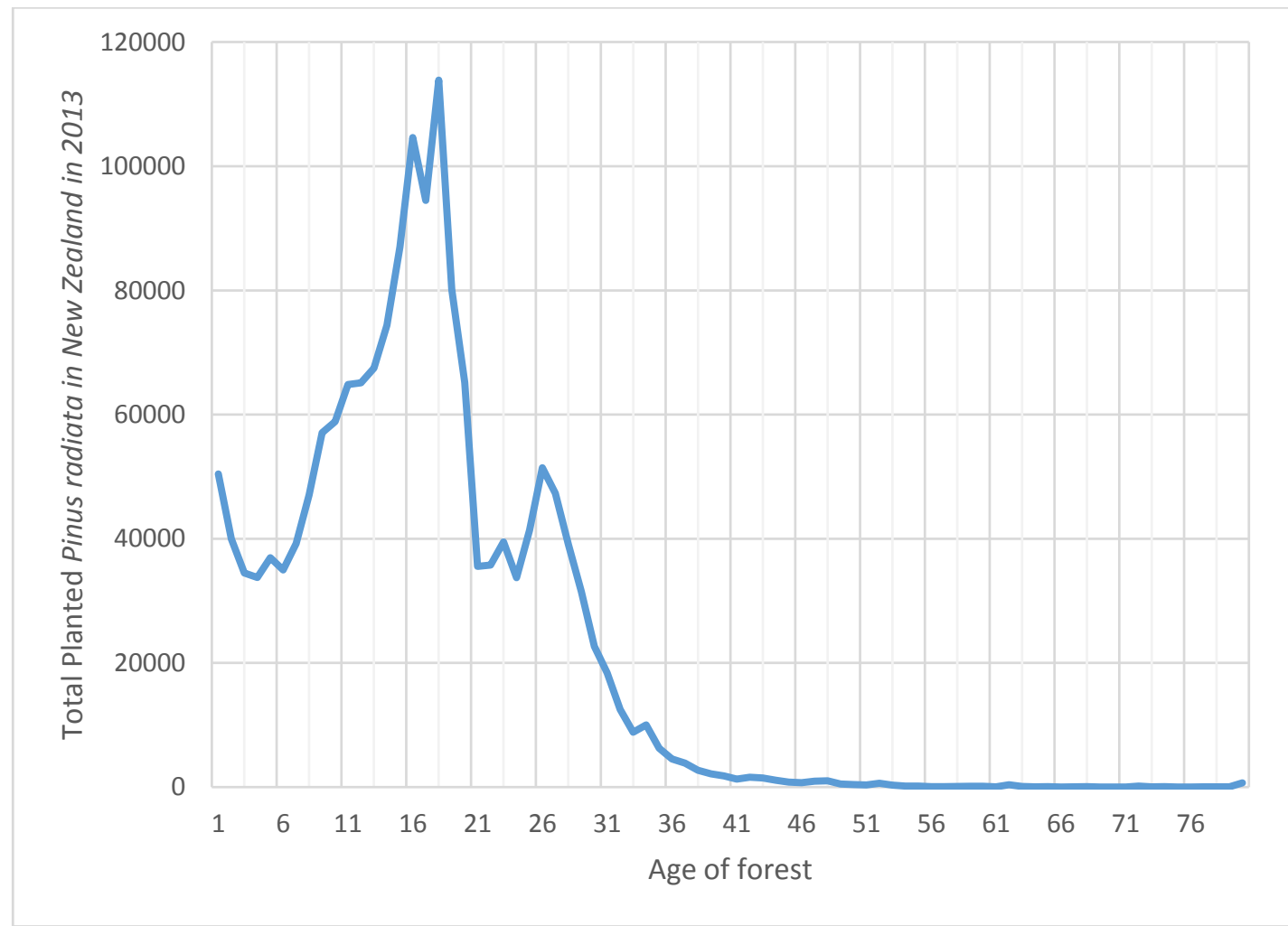

We allow the harvest rate to vary by North and South Island. ${ }^{21}$ These harvest and survival rates are reported in Table 1, which are the harvest rates we use in the harvesting algorithm.

\footnotetext{
${ }^{21}$ We tried varying by WSR, but there was insufficient data to calculate positive harvest rates for all WSRs and age classes 26-40. We could estimate harvesting rates by WSR if we had a time series of planted forest by year and WSR.
} 
The survival rate for each age class is also reported, which is the ex ante probability that a forest block survives past the corresponding age, that is

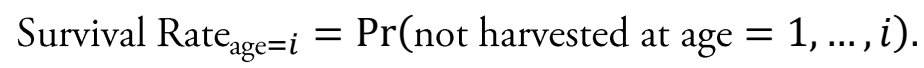

Table 1: Harvest Rate by Island

\begin{tabular}{|c|c|c|c|c|}
\hline & North Island & North Island & South Island & South Island \\
\hline & Harvest Rate & Survival Rate & Harvest Rate & Survival Rate \\
\hline 26 & $5 \%$ & $95 \%$ & $9 \%$ & $91 \%$ \\
\hline 27 & $10 \%$ & $86 \%$ & $17 \%$ & $76 \%$ \\
\hline 28 & $14 \%$ & $74 \%$ & $16 \%$ & $64 \%$ \\
\hline 29 & $20 \%$ & $59 \%$ & $24 \%$ & $49 \%$ \\
\hline 30 & $23 \%$ & $46 \%$ & $21 \%$ & $39 \%$ \\
\hline 31 & $28 \%$ & $33 \%$ & $21 \%$ & $30 \%$ \\
\hline 32 & $29 \%$ & $24 \%$ & $19 \%$ & $25 \%$ \\
\hline 33 & $24 \%$ & $18 \%$ & $14 \%$ & $21 \%$ \\
\hline 34 & $20 \%$ & $14 \%$ & $20 \%$ & $17 \%$ \\
\hline 35 & $17 \%$ & $12 \%$ & $17 \%$ & $14 \%$ \\
\hline 36 & $31 \%$ & $8 \%$ & $26 \%$ & $11 \%$ \\
\hline 37 & $25 \%$ & $6 \%$ & $23 \%$ & $8 \%$ \\
\hline 38 & $22 \%$ & $5 \%$ & $20 \%$ & $6 \%$ \\
\hline 39 & $18 \%$ & $4 \%$ & $33 \%$ & $4 \%$ \\
\hline 40 & $23 \%$ & $3 \%$ & $18 \%$ & $4 \%$ \\
\hline
\end{tabular}


For each year $t$ we harvest harvest rate $e_{i j} \times$ total planted forest $_{i j t}$ pixels of forest in age class $i$ and WSR $j$. The age of remaining planted forests is increased by one year, and stands can be harvested the following year provided its new age is between 26 and 40 . This gives us a map of harvestable forest for 2013-2030. ${ }^{22}$

\section{Estimate stumpage profit for each pixel in each year under the assumptions: (1) it is a pruned forest stand; and (2) it is an unpruned forest stand}

We calculate revenue, cost, and stumpage profits for each 25 ha forest pixel. Stumpage profits account only for revenue and costs incurred at harvest. Therefore planting, pruning, and maintenance costs are ignored; they are sunk costs.

\subsection{Revenue}

Revenue is calculated as follows.

$$
\text { Revenue }_{i j t}=\sum_{k=1}^{3} \text { Price }_{k t} \times \text { Quantity }_{i j t} \text { ' }^{\prime}
$$

Where:

1. WSR $=i$ indicates the stand's wood supply region.

2. Regime $=j$ is either: pruned or not pruned, both without production thinning. ${ }^{23}$

3. Year $=t$ is the simulation year $(t \in\{2014, \ldots, 2030\})$.

4. A 25 ha stand produces up to three log types: pruned (if the forest is a pruned stand), unpruned, and pulp. So $k$ indicates log type, and price $k t$ is the price of log type $k$ at time $t$.

5. Quantity $y_{i j k}$ is the yield of log type $k$ in regime $j$ and WSR $i$.

\footnotetext{
${ }^{22}$ A note to the analyst: Harvest code is located in R: $\backslash$ Environment $\backslash L U R N Z \backslash$ Projects - creating resources $\backslash$ Forestry profitability $\backslash$ Version 5 - MPI Project $\backslash$ Code $\backslash 5$. Profit Map by Year $\backslash$ Code $\backslash$ Profit3.m. To apply this to LURNZ, minor alternations need to be made including changing harvest age assumption. For simplicity I did not keep track of harvested forests' age. One would need to insert an indicator to do this. The code could be faster with a more efficient sorting algorithm.

${ }^{23}$ We lack yield data for forests that have production thinning. So we assume production thinning does not take place.
} 
We use MPI's indicative domestic price series get 2013 price data for: pruned, unpruned, and pulp logs. ${ }^{24}$ Next, we calculate real price changes for logs (this is treated as either pruned or unpruned logs) and pulp using SOPI's inflation and forest forecasts (Ministry for Primary Industries, 2013a). ${ }^{25}$ Price changes are reported in Table 2. Last, we extrapolate the indicative price series using SOPI's forecasts to estimate the prices for pruned, unpruned, and pulp logs in 2014-2017. The 2013 indicative price for: pruned logs is $\$ 130 / \mathrm{m}^{3}$; unpruned logs is $\$ 94 / \mathrm{m}^{3}$; and pulp is $\$ 51 / \mathrm{m}^{3}$. Extrapolated prices are reported in Table 3, and they are calculated as follows:

$$
\begin{gathered}
\text { Price }_{2014}=\left(1+\text { Change }_{2014}\right) \times \text { Indicative Price }_{2013} \text {; and } \\
\text { Price }_{t}=\left(1+\text { Change }_{t}\right) \times \text { Price }_{t-1} \text { for } t=2015-2017 \text {; where } \\
\text { Change }_{t}=\frac{\text { Price }_{t}-\text { Price }_{t-1}}{\text { Price }_{t-1}} .
\end{gathered}
$$

Prices beyond 2017 are assumed to be constant and equal to the forecasted 2017 price.

Table 2: Real forecasted log price

\begin{tabular}{lccccc}
\hline Year & 2013 & 2014 & 2015 & 2016 & 2017 \\
\hline $\begin{array}{llll}\text { Log price (FOB \$ } \\
\text { per } \mathrm{m}^{3} \text { ) }\end{array}$ & $\$ 119$ & $\$ 122.91$ & $\$ 122.55$ & $\$ 124.88$ & $\$ 129.59$ \\
$\begin{array}{l}\text { Change in log price } \\
\text { N/A }\end{array}$ & $+3.3 \%$ & $-0.3 \%$ & $+1.9 \%$ & $+3.8 \%$ \\
$\begin{array}{l}\text { Pulp price (FOB \$ } \\
\text { per tonne) }\end{array}$ & 590 & 561.5 & 558.7 & 569.5 & 591.5 \\
$\begin{array}{l}\text { Change in pulp } \\
\text { price }\end{array}$ & N/A & $-4.8 \%$ & $-0.5 \%$ & $+1.9 \%$ & $+3.9 \%$ \\
\hline
\end{tabular}

\footnotetext{
${ }^{24}$ Go to http:/ /www.mpi.govt.nz/ and search for Indicative NZ Radiata Pine Log Prices. Open the log price series. Select the December 2013 average over 12 quarters price for pruned logs. Go to the domestic price sheet. Let the price of: pruned logs be the average of class P1 and P2; unpruned logs to be the average of class S1, S2, L1\&L2, and S3\&L3; pulp be the class pulp. Go to http://www.mpi.govt.nz/ and search for Indicative NZ Radiata Pine Log Prices. Open the log price series. Select the December 2013 average over 12 quarters price for pruned logs. Let unpruned logs be the average of class A, J, and K.

${ }^{25}$ Inflation is reported in Table 1.1, and forest price estimates are reported in Table 3.1.
} 
Table 3: Forecast real stumpage prices by type (pruned, unpruned, pulp)

\begin{tabular}{lcccc}
\hline Year & 2014 & 2015 & 2016 & 2017 \\
\hline $\begin{array}{l}\text { Pruned logs (domestic } \\
\text { \$ per } \mathrm{m}^{3} \text { ) }\end{array}$ & 129.8 & 134.1 & 133.7 & 136.2 \\
Unpruned logs & 93.5 & 96.6 & 96.3 & \\
$\left(\right.$ domestic \$ per $\left.\mathrm{m}^{3}\right)$ & & & & \\
Pulp (domestic \$ per & 50.8 & 48.3 & 48.1 & 49.0 \\
$\left.\mathrm{~m}^{3}\right)$ & & & & \\
\hline
\end{tabular}

Quantity varies by WSR, age, forest type, regime, and log type. We use NEFD yield tables to estimate quantity. ${ }^{26}$ For each regime there are missing datasheets. The only consistent regimes reported are pruned Pinus radiata stands and unpruned Pinus radiata stands, both without production thinning. We limit our analysis to these two regimes.

\subsection{Forest Cost}

Stumpage costs consist of road construction, harvesting, and cartage cost:

$$
\text { Total cost }_{i j}=\left(\text { Road cost }_{j}+\text { Harvest cost }_{j}+\text { Cartage cost }_{j}\right) \times \text { Quantity }_{i},
$$

Where $j$ indicates forest pixel and $i$ is the WSR. Harvest and road cost depends on island (North or South) and forest gradient, and cartage cost depends on distance to nearest port or mill. ${ }^{27}$ Costs are reproduced below. ${ }^{28,29}$

\footnotetext{
${ }^{26}$ Go to http://www.mpi.govt.nz/ and search for NEFD yield tables. Download the yield tables for each WSR at the bottom of the page. The current yield tables do does not include the West Coast WSR. We use the same yield tables as discussed in Olssen et al. (2012), which "halve the West Coast yield from the earlier tables ... as recommended by Steve Wakelin from Scion Ltd ... [since] it is widely believed that the earlier tables overstated West Coast yields".

${ }^{27}$ Forest gradient and distance to port or mill are calculated in Olssen et al. (2012).

${ }^{28}$ Cost data is restricted. Contact AgriFax, and purchase the Regional Log Price and Cost Report. Go to http://www.nzxagri.com/agrifax for contact details.

${ }^{29}$ Costs are denominated in dollars per tonne. We use the conversion factor of 0.926 for pruned, 0.893 for unpruned, and 0.812 for pulp to convert costs to dollars per $\mathrm{m}^{3}$ as recommended by AgriFax's Forest Analyst Ivan Luketina.
} 
Table 4: Harvest cost (\$ per tonne)

\begin{tabular}{lll}
\hline Gradient & North Island & South Island \\
\hline Flat $\left(0-7^{\circ}\right)$ & 16 & 18 \\
Easy $\left(7-20^{\circ}\right)$ & 19 & 22 \\
Steep $\left(20-25^{\circ}\right)$ & 22 & 25 \\
Very steep $\left(25+^{\circ}\right)$ & 26 & 28 \\
\hline
\end{tabular}

Table 5: Roading cost (\$ per tonne)

\begin{tabular}{lll}
\hline Gradient & North Island & South Island \\
\hline Flat $\left(0-7^{\circ}\right)$ & 3 & 3 \\
Easy $\left(7-20^{\circ}\right)$ & 3 & 3 \\
Steep $\left(20-25^{\circ}\right)$ & 5 & 5 \\
Very steep $\left(25+^{\circ}\right)$ & 8 & 8 \\
\hline
\end{tabular}

Table 6: Cartage cost (\$ per tonne)

\begin{tabular}{ll}
\hline Distance to Port/Mill $(\mathrm{km})$ & Cartage Cost $(\$$ per tonne) \\
\hline $0-40$ & 12 \\
$41-60$ & 15 \\
$61-80$ & 17 \\
$81-100$ & 19 \\
$101-120$ & 23 \\
$121-160$ & 28 \\
$161-200$ & 32 \\
\hline
\end{tabular}




\subsection{Stumpage Profit}

Stumpage profits are calculated as follows.

$$
\text { Stumpage } \text { Profit }_{i j t}=\text { Revenue }_{i t}-\text { Total }_{\operatorname{cost}_{i j}} \text {. }
$$

Therefore, stumpage profits depend on: age of stand harvested; ownership; year; WSR; island; distance to port; and gradient of forestry block. Stumpage profits can now be used to calculate average stumpage profits by WSR for each harvest year. We can also plot a profit distribution.

\section{Assign a pruning regime for each pixel (either pruned or not pruned)}

We cannot determine whether a forest stand has been pruned or not. For each pixel, we calculate stumpage profits under two assumptions: it is pruned and it is not pruned. We assign a proportion of pixels with the highest 2013 pruned stumpage profit as pruned (forest owners are more likely to prune blocks that they believe will yield higher profits). ${ }^{30}$ In the end, imputed pruned forests are assigned pruned stumpage profits; remaining forests are assigned unpruned stumpage profits.

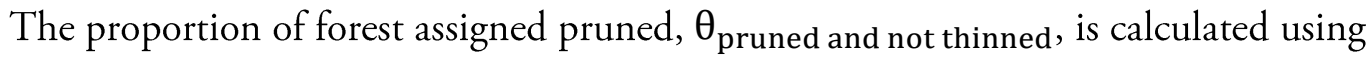
Tables 9.14-9.17 in the 2013 NEFD (Ministry for Primary Industries, 2013b). In particular, $\theta_{\mathrm{ij}}$ is equal to the proportion of forest planted in regime $j$ and wood supply region (WSR) $i{ }^{31} \mathrm{We}$ have reported the proportion of pruned forest by regime in Table $7 .{ }^{32}$

Each forest pixel now has a stumpage profit associated with it. We have forest maps for years 2013-2030. We use this to calculate average stumpage profit by WSR and stumpage profit distributions by year.

\footnotetext{
${ }^{30}$ Pruning regime is determined in the 2013 map, and carried through to all other maps.

31 We are implicitly assuming that the proportion of pruned forest will remain constant from 2013-2030. The NEFD report might be underestimating the number of pruned forest: forest owners do not decide on pruning regimes until the forest is aged 10, and very few forest owners declare that they will prune the forest when it is less than 10 years old.

32 We assume that all forests that will be harvested by 2030 have already been pruned in 2013 if they are going to be pruned. The youngest are 9 years old.
} 
Table 7: Proportion of Pruned and Unpruned Planted Forest by WSR (2013)

\begin{tabular}{|c|c|c|}
\hline WSR & Pruned & Unpruned \\
\hline Northland & 0.42 & 0.58 \\
\hline Auckland & 0.34 & 0.66 \\
\hline Central North Island & 0.46 & 0.54 \\
\hline North Island East Cost & 0.73 & 0.27 \\
\hline Hawke's Bay & 0.69 & 0.31 \\
\hline $\begin{array}{l}\text { Southern North Island } \\
\text { West }\end{array}$ & 0.67 & 0.33 \\
\hline $\begin{array}{l}\text { Southern North Island } \\
\text { East }\end{array}$ & 0.67 & 0.33 \\
\hline Nelson & 0.25 & 0.75 \\
\hline Marlborough & 0.53 & 0.47 \\
\hline West Coast & 0.54 & 0.46 \\
\hline Canterbury & 0.44 & 0.56 \\
\hline Otago & 0.69 & 0.31 \\
\hline Southland & 0.55 & 0.45 \\
\hline
\end{tabular}

\section{Interpret the results}

In this section we discuss the main results of our harvest simulation. In particular, we produce stumpage profit tables, histograms, and maps. We also compare stumpage profits by wood supply region and year. 


\subsection{All Forests}

Average stumpage profits (denominated in 2013 dollars per hectare) by year and wood supply region are reported in Table 10 (tables and figures for the results section are reported in Appendix: Tables and Figures). We compare stumpage profits by WSR in Figure 2 which shows simulated average stumpage profits over years 2013-2030 for each WSR. All regions except for West Coast and Canterbury have average stumpage profits in the range $\$ 27,400-\$ 38,500$ per hectare. ${ }^{33}$ West Coast's simulated average stumpage profit over $2013-2030$ is $\$ 12,600$ per hectare, which is well below the mean $(\$ 30,000$ per hectare). Canterbury's simulated average stumpage profit is equal to $\$ 21,700$ per hectare over $2013-2030$.

Figure 2: Average Stumpage Profit over 2013-2030 by Wood Supply Region for All Planted Forest

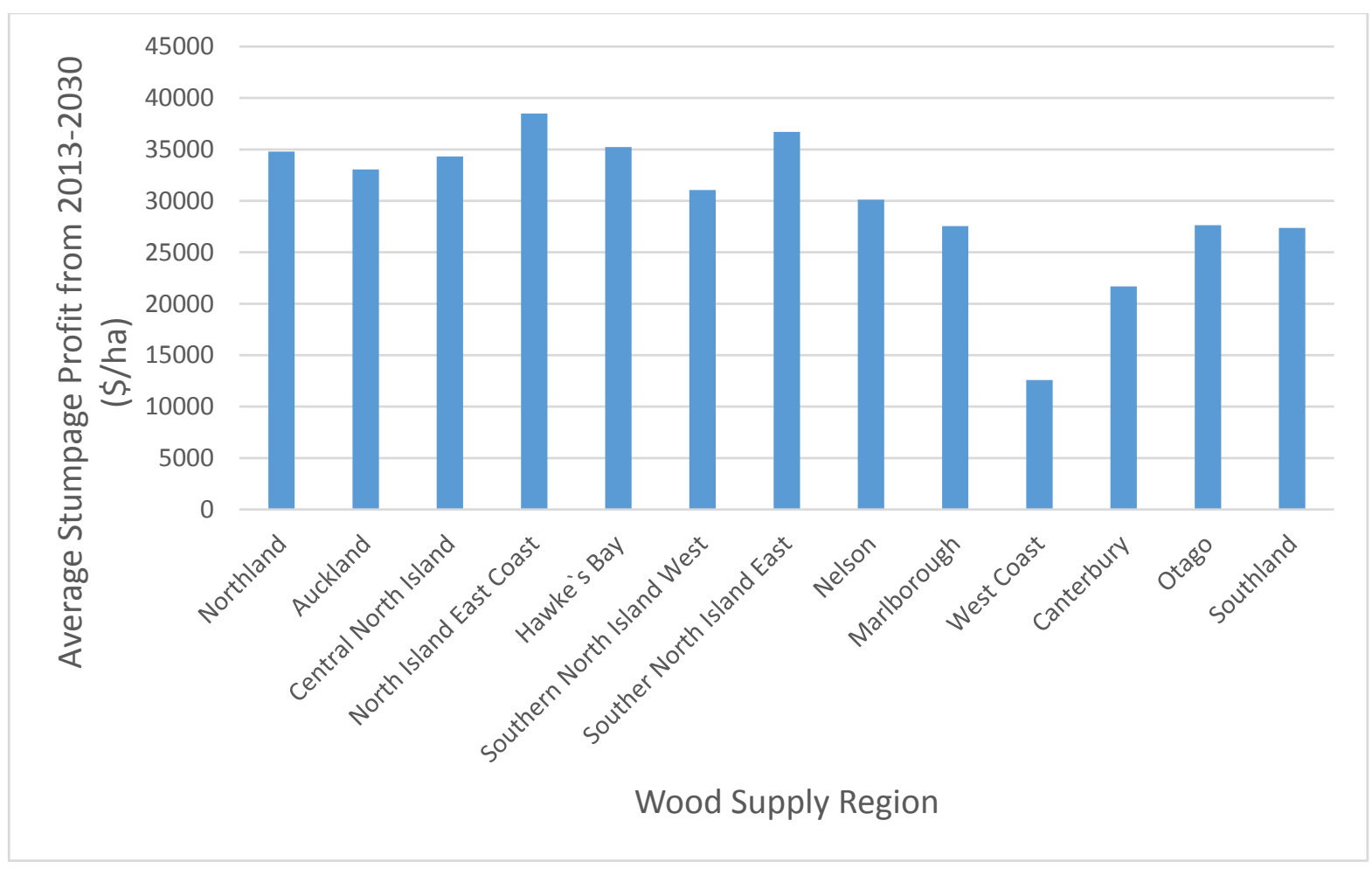

${ }^{33}$ We round stumpage profits to the nearest $\$ 100$. 
Figure 3 compares simulated average stumpage profit over WSR by year (2013-2030). Between 2013 and 2018 average real stumpage profits are projected to increase from $\$ 25,600$ to $\$ 30,800$ per hectare. Stumpage profits fall from 2018 to 2021 (down to $\$ 29,800$ per hectare), then gradually rise to $\$ 32,200$ per hectare in 2030 .

Figure 3: Average Stumpage Profit over Wood Supply Regions by Year for All Planted Forest

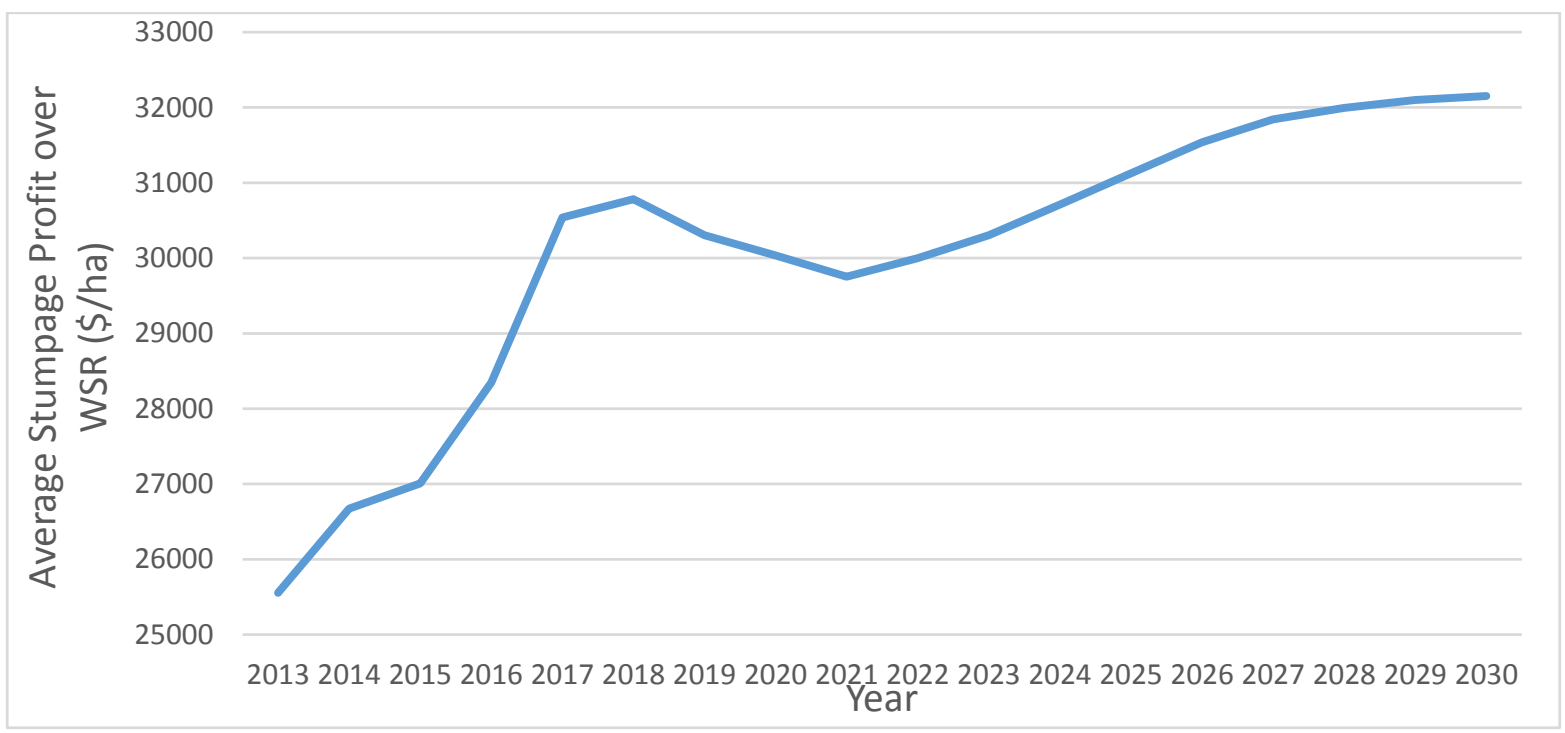

We produce stumpage profit histograms for each year (2013-2030). Figure 4 and Figure 5 are the stumpage profit histograms for 2013 and 2030. Both histograms are unimodal, but they are not normally distributed. In 2013 the right tail is smooth and diminishes to zero. The left tail has a large drop in frequency in the $\$ 20,000-22,300$ bin. This pattern persists in the 2030 histogram. The right tail, however, is thicker in 2030. Simulated average stumpage profits increase from $\$ 25,600$ to $\$ 32,200$ per hectare. Standard deviation also increases from $\$ 7,000$ to $\$ 9,500$ per hectare. Therefore, the coefficient of variation, $c=\frac{\sigma}{\mu}$, increases from 0.26 to 0.28 , as well. The increase in $C$ implies that the relative disparity of stumpage profits between 2013 and 2030 increases (but not by much). 
Figure 4: Histogram of Stumpage Profit for 2013 for All Planted Forest

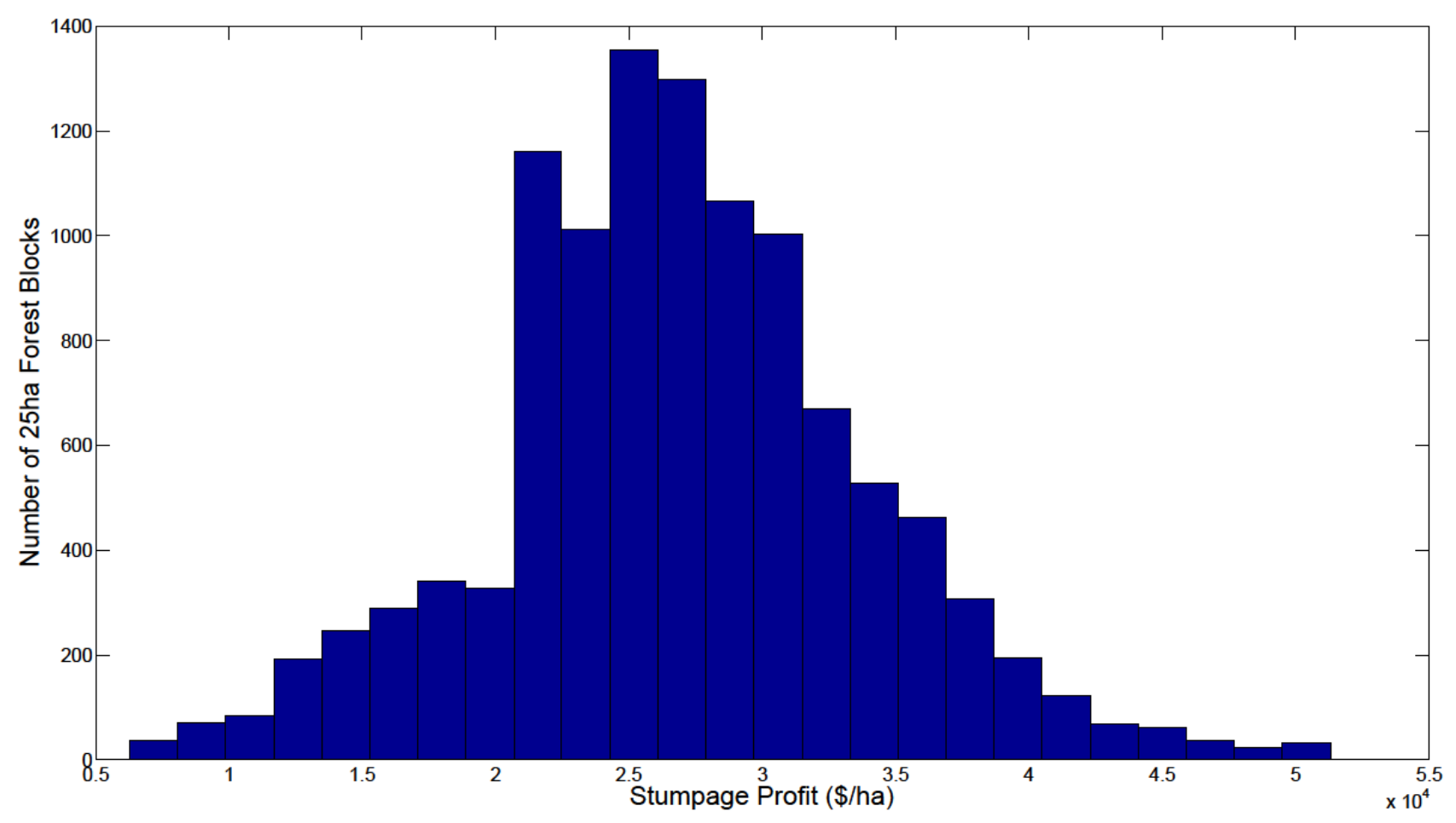

Figure 5: Histogram of Stumpage Profit for 2030 for All Planted Forest

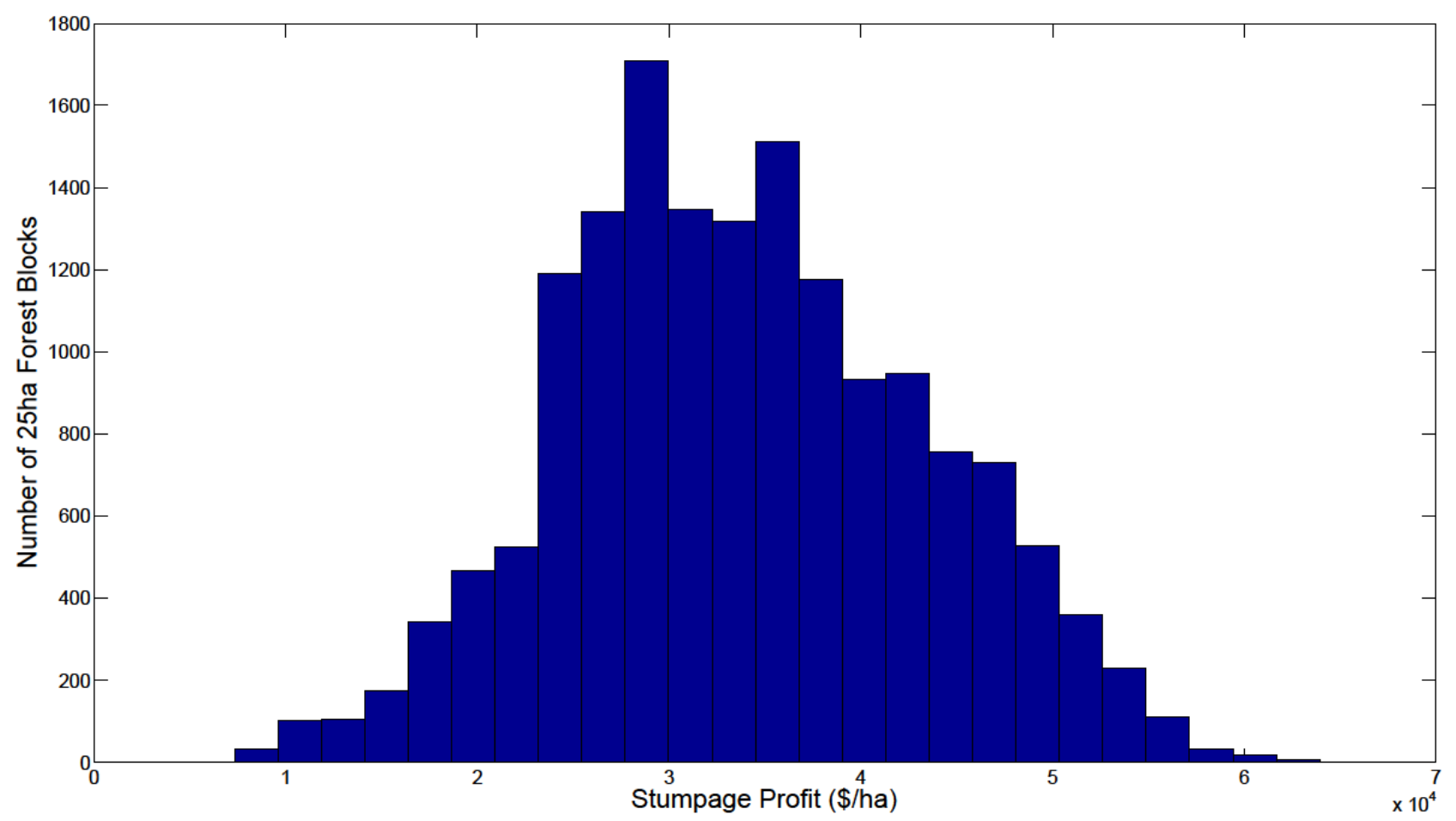


Last, stumpage profit maps for 2013 and 2030 are included (Figure 6 and Figure 7 in Appendix). Map resolution (size of pixel) is 25 hectares. White pixels are non-harvestable forest and grey pixels are sea. Remaining pixels are coloured either red (forest stands with simulated stumpage profit less than $\$ 20,100$ per hectare); magenta, blue, cyan (forest stands with simulated stumpage profit between $\$ 20,100$ and $\$ 49,000$ per hectare); or green (forest stands with simulated stumpage profit more than $\$ 49,000$ per hectare). We can see that the North Island is more profitable in 2030 than in 2013, and the West Coast's relatively low stumpage profits is persistent through time. We now compare stumpage profits for post- 89 and pre- 90 forests.

\subsection{Post-89 versus Pre-90}

Average stumpage profits by WSR and year (2013-2030) for pre-90 and post-89 forests are reported in

Table 11 and

Table 12, respectively. There are no harvestable post- 89 forest stands until 2015 when the first stands reach age 26; this is why the first two columns in

Table 12 are filled with N/A values.

We compare average stumpage profits over 2013-2030 by wood supply region for pre-90 and post-89 forest in Figure 8: Average Stumpage Profit over 2013-2030 by Wood Supply Region by Forest TypeFigure 8: Post- 89 forests appear $\$ 10,300$ per hectare more profitable than pre-90 forests in the Central North Island WSR; post-89 forests are $\$ 5,700$ per hectare more profitable than pre-90 forests in the Auckland WSR; and post-89 forests are $\$ 4,610$ per hectare more profitable than pre-90 forests in the Otago WSR; Remaining wood supply regions differ at most by $\$ 4,000$ per hectare.

Stumpage profit histograms for each forest type (pre-90 and post-89) in 2030 are reported Figure 10 and Figure $11 .^{34}$

\footnotetext{
342030 is the first year that post-89 forests have a full age-class distribution (from 1-41). It makes sense to compare histograms and stumpage profit maps in 2030, but no earlier.
} 
The histogram for pre-90 forests has stumpage profits concentrated near the mean, it is unimodal, and it follows the same asymmetric pattern as in the all forest case. The mean is $\$ 30,200$ per hectare, the standard deviation is $\$ 7,400$, and the coefficient of variation is $c=$ 0.25. There is a significant amount of variation in stumpage profits: the maximum stumpage profit is $\$ 57,900$ (3.75 standard deviations above the mean), and the minimum stumpage profit is $\$ 7,400$ (3.08 standard deviations below the mean).

On the other hand, the histogram for post- 89 forests looks closer to uniform distribution than a normal distribution. The mean is $\$ 37,600$, the standard deviation is $\$ 9,800$, and the coefficient of variation is $c=0.26$ (implying that post- 89 forest stands have slightly more dispersion than for pre-90 forest stands). The maximum is $\$ 64,900$ (2.76 standard deviations above the mean), and the minimum is $\$ 9,000$ (2.91 standard deviations below the mean). We also produce stumpage profit maps for pre-90 (Figure 12) and post-89 (Figure 13) forests.

Following the procedure in Olssen et al. (2012) but updating and using our updated methodology for stumpage we produce measures of net present value (NPV), internal rate of return (IRR), land expectation value (LEV) and expected annual earnings (EAE). These are shown by wood supply region in Table 8 . Figure 14 and Figure 15 are the NPV maps for pre-90 and post- 89 forests, respectively. When the real subjective discount rate is equal to $7 \%$ we find that NPV is positive for most forest stands in Nelson, Northland, Central North Island, and North Island East Coast. NPV is negative elsewhere, so forest owners may choose not to replant after harvest in these regions. Figure 16 and Figure 17 are the IRR maps for pre-90 and post-89 forests, respectively. Most of the North Island stands have IRR equal to $6.5 \%$ or above. All forest stands excluding the West Coast and patches of forest in the South Island have IRR equal to $5 \%$ or higher. ${ }^{35}$ This suggests that foresters probably will not replant in the South Island (other than Nelson) unless their discount rate is lower than 7\%, say around 5\%. For replanting on the West Coast, investors could get a higher rate of return from Treasury Bonds.

${ }^{35}$ Forest stands with IRR less than $5 \%$ in Nelson and Canterbury are on steep land. 
Table 8 Mean expected forest profit by WSR for land in radiata pine in 2013

\begin{tabular}{lcccr}
\hline $7 \%$ discount rate & NPV & IRR & LEV & EAE \\
\hline Northland & 490 & 7.65 & 577 & 40 \\
Auckland & 450 & 7.44 & 529 & 37 \\
Central North Island & 671 & 7.71 & 789 & 55 \\
East Coast & 507 & 7.43 & 597 & 42 \\
Hawke's Bay & 228 & 7.34 & 268 & 19 \\
Southern North Island East Coast & 327 & 7.21 & 385 & 27 \\
Southern North Island West Coast & -312 & 6.77 & -367 & -26 \\
Marlborough & -492 & 6.36 & -579 & -41 \\
Nelson & 251 & 7.37 & 296 & 21 \\
West Coast & -2421 & 1.99 & - & - \\
& & & 2850 & 199 \\
Canterbury & -1127 & 5.19 & - & -93 \\
& & & 1327 & -68 \\
Otago & -827 & 5.9 & -973 & -50 \\
Southland & -610 & 6.2 & -718 & 5 \\
New Zealand Weighted Average & 61 & 6.96 & 72 & \\
\hline
\end{tabular}

In short, stumpage profit for the average forest is increasing through time, and stumpage profits are significantly lower for West Coast than any other wood supply region. Our 2030 simulation shows that post- 89 forests have higher stumpage profits than pre-90 forests (averaged over New Zealand). We also show that post- 89 forests have much higher stumpage profits than pre-90 forests in the Central North Island wood supply region.

Our stumpage analysis does not include fixed costs per block at harvest (management costs, costs to move forestry equipment, forest permits). These will have a greater impact on average stumpage per hectare for small forest stands than large ones. Including fixed costs at harvest, as well as unobserved variation in yield, harvest and transport, is likely to increase the dispersion of stumpage profit and may lead to non-harvest of some blocks. 


\section{References}

Anastasiadis, Simon, Suzi Kerr, Wei Zhang, Corey Allan, and William Power. 2014. Land Use in Rural New Zealand: Spatial Land Use, Land-Use Change, and Model Validation. Motu Working Paper 14-07. Motu Working Paper Series. Wellington, New Zealand: Motu Economic and Public Policy Research. www.motu.org.nz/publications/detail/land_use_in_rural_new_zealand_spatial_land_use _land-use_change_and_model_va.

Ministry for Primary Industries. 2013a. "Situation and Outlook for Primary Industries."

_. 2013b. "National Exotic Forest Description as at 1 April 2013."

Ministry of Agriculture and Forestry, New Zealand Forest Owners Association, and New Zealand Farm Forestry Association. 2012. National Exotic Forest Description as at 1 April 2011. Wellington: Ministry of Agriculture and Forestry. http://www.maf.govt.nz/newsresources/publications.

Olssen, Alex, Wei Zhang, David Evison, and Suzi Kerr. 2012. A Forest-Profit Expectations Dataset for New Zealand, 1990-2008. Wellington: Motu Economic and Public Policy Research. http://www.motu.org.nz/publications/detail/a_forestprofit_expectations_dataset_for_new_zealand_19902008.

Timar, Levente. 2011. Rural Land Use and Land Tenure in New Zealand. Motu Working Paper 11-13. Motu Working Paper Series. Wellington: Motu Economic and Public Policy Research.

Zhang, Wei, and Suzi Kerr. 2011. Creating New Zealand Forestry Age Maps in 2002 and 2008 and Estimating and Projecting Plantation Forest Removals and Emissions in LURNZ. Draft. Wellington: Motu Economic and Public Policy Research. 


\section{Appendix: Tables and Figures}

Table 9: Compare Area for the 2013 LURNZ and NEFD Dataset

\begin{tabular}{|c|c|c|c|c|}
\hline Territory Authority & $\begin{array}{l}\text { LURNZ Area } \\
\text { (ha) }\end{array}$ & $\begin{array}{l}\text { NEFD Area } \\
\text { (ha) }\end{array}$ & $\begin{array}{l}\text { NEFD - } \\
\text { LURNZ Area } \\
\text { (ha) }\end{array}$ & $\begin{array}{l}\text { Absolute } \\
\text { value of error } \\
\text { as percentage }\end{array}$ \\
\hline Far North District & 75,550 & 91494 & 15,944 & $17 \%$ \\
\hline Whangarei District & 31,175 & 31711 & 536 & $2 \%$ \\
\hline Kaipara District & 38,950 & 38354 & -596 & $2 \%$ \\
\hline Auckland Council & 33,250 & 40908 & 7,658 & $19 \%$ \\
\hline Papakura District & 175 & 49 & -126 & $72 \%$ \\
\hline Franklin District & 6,950 & 43 & $-6,907$ & $99 \%$ \\
\hline Thames-Coromandel District & 9,650 & 16332 & 6,682 & $41 \%$ \\
\hline Hauraki District & 3,175 & 3255 & 80 & $2 \%$ \\
\hline Waikato District & 14,875 & 18271 & 3,396 & $19 \%$ \\
\hline Matamata-Piako District & 1,400 & 1400 & 0 & $0 \%$ \\
\hline Hamilton City & 0 & 1 & 1 & \\
\hline Waipa District & 2,825 & 2709 & -116 & $4 \%$ \\
\hline Otorohanga District & 5,225 & 5057 & -168 & $3 \%$ \\
\hline South Waikato District & 70,275 & 62687 & $-7,588$ & $11 \%$ \\
\hline Waitomo District & 20,125 & 25651 & 5,526 & $22 \%$ \\
\hline Taupo District & 111,700 & 169338 & 57,638 & $34 \%$ \\
\hline $\begin{array}{l}\text { Western Bay Of Plenty } \\
\text { District }\end{array}$ & 15,650 & 23731 & 8,081 & $34 \%$ \\
\hline Tauranga District & 350 & 110 & -240 & $69 \%$ \\
\hline Rotorua District & 33,175 & 51384 & 18,209 & $35 \%$ \\
\hline Whakatane District & 46,300 & 104348 & 58,048 & $56 \%$ \\
\hline Kawerau District & 25 & 34 & 9 & $26 \%$ \\
\hline
\end{tabular}




\begin{tabular}{|c|c|c|c|}
\hline Opotiki District & 18,675 & 16631 & $-2,044$ \\
\hline Gisborne District & 119,025 & 154289 & 35,264 \\
\hline Wairoa District & 40,875 & 53890 & 13,015 \\
\hline Hastings District & 48,425 & 60129 & 11,704 \\
\hline Napier City & 175 & 139 & -36 \\
\hline Central Hawkes Bay District & 13,575 & 15405 & 1,830 \\
\hline New Plymouth District & 4,925 & 4005 & -920 \\
\hline Stratford District & 38,50 & 6398 & 2,548 \\
\hline South Taranaki District & 14,100 & 9859 & $-4,241$ \\
\hline Ruapehu District & 36,400 & 46787 & 10,387 \\
\hline Wanganui District & 21,075 & 28315 & 7,240 \\
\hline Rangitikei District & 19,475 & 21911 & 2,436 \\
\hline Manawatu District & 7,925 & 6646 & $-1,279$ \\
\hline Palmerston North City & 2,950 & 2271 & -679 \\
\hline Tararua District & 17,625 & 15885 & $-1,740$ \\
\hline Horowhenua District & 6,925 & 6717 & -208 \\
\hline Kapiti Coast District & 4,375 & 3664 & -711 \\
\hline Porirua City & 2,250 & 1391 & -859 \\
\hline Upper Hutt City & 3,375 & 6240 & 2,865 \\
\hline Lower Hutt City & 350 & 299 & -51 \\
\hline Wellington City & 1,125 & 319 & -806 \\
\hline Masterton District & 27,250 & 32880 & 5,630 \\
\hline Carterton District & 9,125 & 10341 & 1,216 \\
\hline South Wairarapa District & 5,450 & 8481 & 3,031 \\
\hline Tasman District & 69,250 & 86386 & 17,136 \\
\hline Nelson City & 7,225 & 8757 & 1,532 \\
\hline
\end{tabular}




\begin{tabular}{|c|c|c|c|c|}
\hline Marlborough District & 57,475 & 71473 & 13,998 & $20 \%$ \\
\hline Kaikoura District & 1,525 & 1345 & -180 & $12 \%$ \\
\hline Buller District & 4,800 & 3869 & -931 & $19 \%$ \\
\hline Grey District & 13,625 & 13940 & 315 & $2 \%$ \\
\hline Westland District & 12,875 & 14657 & 1,782 & $12 \%$ \\
\hline Hurunui District & 31,775 & 38997 & 7,222 & $19 \%$ \\
\hline Waimakariri District & 8,675 & 12458 & 3,783 & $30 \%$ \\
\hline Christchurch City & 1,400 & 6015 & 4,615 & $77 \%$ \\
\hline Banks Peninsula District & 5,225 & 5465 & 240 & $4 \%$ \\
\hline Selwyn District & 17,350 & 13863 & $-3,487$ & $20 \%$ \\
\hline Ashburton District & 6,225 & 3776 & $-2,449$ & $39 \%$ \\
\hline Timaru District & 12,875 & 11868 & $-1,007$ & $8 \%$ \\
\hline Mackenzie District & 4,925 & 4832 & -93 & $2 \%$ \\
\hline Waimate District & 13,050 & 11629 & $-1,421$ & $11 \%$ \\
\hline Waitaki District & 21,050 & 18097 & $-2,953$ & $14 \%$ \\
\hline Central Otago District & 9,275 & 6985 & $-2,290$ & $25 \%$ \\
\hline Queenstown-Lakes District & 3,300 & 875 & $-2,425$ & $73 \%$ \\
\hline Dunedin City & 18,700 & 14501 & $-4,199$ & $22 \%$ \\
\hline Clutha District & 72,100 & 81143 & 9,043 & $11 \%$ \\
\hline Southland District & 68,300 & 77041 & 8,741 & $11 \%$ \\
\hline Gore District & 4,850 & 4404 & -446 & $9 \%$ \\
\hline Invercargill City & 850 & 683 & -167 & $20 \%$ \\
\hline Unidentified & 325 & 0 & -325 & \\
\hline Total & $1,417,125$ & $1,712,818$ & 295,693 & 17 \\
\hline
\end{tabular}


Table 10: Average Stumpage Profit by Year and WSR for All Planted Forest (\$/ha)

\begin{tabular}{lcccccccccc}
\hline Year & 2013 & 2014 & 2015 & 2016 & 2017 & 2018 & 2019 & 2020 & 2021 & 2022 \\
\hline Northland & 28350 & 29352 & 29942 & 31677 & 34654 & 35588 & 35952 & 36148 & 35648 & 35589 \\
Auckland & 28901 & 29693 & 29803 & 31031 & 32778 & 32658 & 32418 & 32462 & 32733 & 33317 \\
Central North Island & 27918 & 29049 & 29636 & 31130 & 33781 & 34242 & 34947 & 35416 & 35668 & 35981 \\
North Island East Coast & 31648 & 33236 & 34040 & 35202 & 38033 & 38742 & 38915 & 38527 & 38579 & 38986 \\
Hawke`s Bay & 29014 & 30375 & 31099 & 32923 & 35570 & 35748 & 34997 & 34968 & 34854 & 35390 \\
Southern North Island & 28643 & 29700 & 29513 & 30145 & 31888 & 31945 & 31074 & 30614 & 30047 & 30230 \\
West & 31663 & 32814 & 33219 & 35258 & 37455 & 37247 & 36144 & 35920 & 36266 & 36616 \\
Southern North Island East & 27034 & 28592 & 28655 & 29560 & 31577 & 30865 & 29984 & 29387 & 28875 & 29211 \\
Nelson & 22739 & 24475 & 24403 & 26200 & 28788 & 29780 & 28624 & 27311 & 26217 & 26228 \\
Marlborough & 11244 & 11991 & 12247 & 13107 & 14132 & 14202 & 13127 & 12590 & 12294 & 12109 \\
West Coast & 19791 & 20627 & 20666 & 21192 & 22641 & 22629 & 22291 & 21869 & 21362 & 21437 \\
Canterbury & 21322 & 21922 & 22487 & 24467 & 27003 & 27566 & 27610 & 28043 & 27668 & 28099 \\
Otago & 23931 & 24942 & 25396 & 26620 & 28694 & 28936 & 27872 & 27218 & 26571 & 26806 \\
Southland & 25554 & 26674 & 27008 & 28347 & 30538 & 30781 & 30304 & 30036 & 29752 & 30000 \\
Average & & & & & & & & & &
\end{tabular}


Table 10: Continued

\begin{tabular}{lccccccccc}
\hline Year & 2023 & 2024 & 2025 & 2026 & 2027 & 2028 & 2029 & 2030 & Average \\
\hline Northland & 35689 & 35950 & 36500 & 36919 & 37289 & 37272 & 37032 & 36467 & 34779 \\
Auckland & 33778 & 34479 & 35013 & 35139 & 35280 & 35188 & 35085 & 35122 & 33049 \\
Central North Island & 36194 & 36372 & 36283 & 36316 & 36206 & 36205 & 36162 & 36105 & 34312 \\
North Island East Coast & 39556 & 40122 & 40824 & 41311 & 41680 & 41241 & 41007 & 41279 & 38496 \\
Hawke`s Bay & 36026 & 36723 & 37541 & 38173 & 38341 & 37944 & 37544 & 37063 & 35239 \\
Southern North Island & 30595 & 30885 & 31262 & 31704 & 32214 & 32601 & 32790 & 33045 & 31050 \\
West & 36881 & 37223 & 37828 & 38337 & 38898 & 39253 & 39598 & 40005 & 36701 \\
Southern North Island East & 29649 & 30262 & 30756 & 31258 & 31554 & 31655 & 31590 & 31543 & 30112 \\
Nelson & 26588 & 27242 & 27790 & 28737 & 29437 & 29840 & 30543 & 30993 & 27552 \\
Marlborough & 11960 & 12022 & 12181 & 12260 & 12494 & 12633 & 12832 & 13008 & 12580 \\
West Coast & 21296 & 21510 & 21788 & 21982 & 22152 & 22362 & 22583 & 22281 & 21692 \\
Canterbury & 28496 & 28878 & 29100 & 29971 & 30262 & 31095 & 31502 & 31769 & 27626 \\
Otago & 27230 & 27572 & 27747 & 27881 & 28143 & 28640 & 29014 & 29286 & 27361 \\
Southland & 30303 & 30711 & 31124 & 31538 & 31842 & 31995 & 32099 & 32151 & 30042 \\
Total & & & & & & &
\end{tabular}


Table 11: Average Stumpage Profit by Year and WSR for Pre-90 Planted Forest ( $\$ /$ ha)

\begin{tabular}{lcccccccccc}
\hline Year & 2013 & 2014 & 2015 & 2016 & 2017 & 2018 & 2019 & 2020 & 2021 & 2022 \\
\hline Northland & 28350 & 29352 & 29913 & 31617 & 34531 & 35262 & 35611 & 35950 & 35526 & 34840 \\
Auckland & 28901 & 29693 & 29776 & 30832 & 32271 & 31858 & 31238 & 30740 & 30477 & 30437 \\
Central North Island & 27918 & 29049 & 29272 & 30464 & 32694 & 32859 & 33197 & 33274 & 33095 & 33001 \\
North Island East Coast & 31648 & 33236 & 34124 & 35686 & 38782 & 39379 & 39594 & 38835 & 37738 & 37359 \\
Hawke`s Bay & 29014 & 30375 & 31176 & 33218 & 35882 & 36021 & 35522 & 35222 & 34790 & 34146 \\
Southern North Island West & 28643 & 29700 & 29900 & 31221 & 33545 & 33697 & 33206 & 32932 & 31700 & 31760 \\
Southern North Island East & 31663 & 32814 & 33314 & 35445 & 37982 & 38343 & 37654 & 37033 & 36839 & 36906 \\
Nelson & 27034 & 28592 & 29355 & 30260 & 32209 & 31688 & 31550 & 30963 & 30656 & 30557 \\
Marlborough & 22739 & 24475 & 25551 & 27682 & 30477 & 32098 & 32957 & 33091 & 32695 & 32290 \\
West Coast & 11244 & 11991 & 12294 & 13269 & 14464 & 14731 & 14339 & 14329 & 14055 & 13583 \\
Canterbury & 19791 & 20627 & 21035 & 22077 & 23788 & 23935 & 24157 & 24105 & 23831 & 23780 \\
Otago & 21322 & 21922 & 22381 & 24307 & 26798 & 27257 & 27539 & 27463 & 26612 & 26066 \\
Southland & 23931 & 24942 & 25706 & 27289 & 29456 & 29892 & 29590 & 28811 & 27956 & 27528 \\
Average & 25554 & 26674 & 27215 & 28721 & 30991 & 31309 & 31243 & 30981 & 30459 & 30173 \\
\hline
\end{tabular}


Table 11: Continued

\begin{tabular}{lccccccccc}
\hline Year & 2023 & 2024 & 2025 & 2026 & 2027 & 2028 & 2029 & 2030 & Average \\
\hline Northland & 34293 & 33953 & 33381 & 33052 & 32752 & 32163 & 31536 & 31453 & 32974 \\
Auckland & 30291 & 30638 & 31068 & 31067 & 30983 & 30507 & 30041 & 29987 & 30600 \\
Central North Island & 32731 & 32415 & 32045 & 31966 & 31948 & 32018 & 32080 & 32324 & 31797 \\
North Island East Coast & 36534 & 35265 & 34764 & 34702 & 34438 & 33446 & 33114 & 33402 & 35669 \\
Hawkes Bay & 33695 & 33231 & 32598 & 31914 & 31096 & 30813 & 30963 & 30729 & 32800 \\
Southern North Island & 31648 & 31504 & 31871 & 32002 & 32027 & 31947 & 32180 & 32034 & 31751 \\
West & 36512 & 34831 & 35179 & 34975 & 34476 & 34164 & 33882 & 33993 & 35334 \\
Southern North Island East & 30529 & 30651 & 30448 & 30718 & 30684 & 30532 & 30238 & 30278 & 30386 \\
Nelson & 31119 & 30526 & 29783 & 29259 & 28125 & 26493 & 26588 & 27225 & 29065 \\
Marlborough & 13161 & 12358 & 12082 & 11800 & 11600 & 11339 & 11339 & 11600 & 12754 \\
West Coast & 23017 & 22724 & 22108 & 21734 & 21778 & 21611 & 21681 & 20868 & 22369 \\
Canterbury & 25822 & 26000 & 25740 & 25527 & 24143 & 24149 & 23094 & 23358 & 24972 \\
Otago & 27096 & 26630 & 26605 & 26116 & 25088 & 24738 & 24191 & 24332 & 26661 \\
Southland & 29727 & 29287 & 29052 & 28833 & 28395 & 27994 & 27764 & 27814 & 29010 \\
Average & & & & & &
\end{tabular}


Table 12: Average Stumpage Profit by Year and WSR for Post-89 Planted Forest ( $\$ /$ ha)

\begin{tabular}{lllllllllll}
\hline Year & 2013 & 2014 & 2015 & 2016 & 2017 & 2018 & 2019 & 2020 & 2021 & 2022 \\
\hline Northland & N/A & N/A & 30188 & 31902 & 34966 & 36254 & 36402 & 36326 & 35719 & 35934 \\
Auckland & N/A & N/A & 30116 & 32113 & 35155 & 36287 & 34819 & 34673 & 34707 & 35475 \\
Central North Island & N/A & N/A & 34376 & 36704 & 40152 & 41336 & 41876 & 42104 & 41720 & 41914 \\
North Island East Coast & N/A & N/A & 32781 & 34022 & 37091 & 38215 & 38577 & 38444 & 38750 & 39271 \\
Hawke`s Bay & N/A & N/A & 29426 & 31252 & 34489 & 35137 & 34585 & 34871 & 34868 & 35618 \\
Southern North Island West & N/A & N/A & 24552 & 26163 & 28593 & 29432 & 29348 & 29436 & 29475 & 29802 \\
Southern North Island East & N/A & N/A & 31643 & 33601 & 35259 & 35290 & 35099 & 35433 & 36081 & 36547 \\
Nelson & N/A & N/A & 22062 & 24488 & 27256 & 27129 & 26210 & 26610 & 26707 & 27657 \\
Marlborough & N/A & N/A & 19097 & 21514 & 24375 & 25325 & 24577 & 24349 & 24396 & 24968 \\
West Coast & N/A & N/A & 9493 & 9832 & 11092 & 11253 & 10617 & 10758 & 11032 & 11263 \\
Canterbury & N/A & N/A & 16877 & 17653 & 19674 & 20239 & 20387 & 20355 & 20214 & 20568 \\
Otago & N/A & N/A & 23638 & 25638 & 27903 & 28530 & 27703 & 28618 & 28380 & 29132 \\
Southland & N/A & N/A & 21622 & 23023 & 25733 & 26484 & 25742 & 25935 & 25857 & 26495 \\
Average & N/A & N/A & 25067 & 26762 & 29364 & 30070 & 29688 & 29839 & 29839 & 30357 \\
\hline
\end{tabular}


Table 10: Continued

\begin{tabular}{lccccccccc}
\hline Year & 2023 & 2024 & 2025 & 2026 & 2027 & 2028 & 2029 & 2030 & Average \\
\hline Northland & 36235 & 36639 & 37631 & 38447 & 39394 & 40038 & 40911 & 41390 & 36774 \\
Auckland & 36324 & 37371 & 37918 & 38359 & 38254 & 38957 & 39732 & 40510 & 36298 \\
Central North Island & 41682 & 42331 & 43067 & 44016 & 44823 & 45245 & 46065 & 46784 & 42137 \\
North Island East Coast & 40039 & 40925 & 41770 & 42340 & 42853 & 42768 & 42969 & 43598 & 39651 \\
Hawke`s Bay & 36401 & 37278 & 38422 & 39640 & 40640 & 41090 & 41511 & 41867 & 36693 \\
Southern North Island West & 30309 & 30712 & 31099 & 31628 & 32268 & 32813 & 33003 & 33430 & 30129 \\
Southern North Island East & 36955 & 37728 & 38375 & 38991 & 39861 & 40582 & 41170 & 41939 & 37160 \\
Nelson & 28620 & 29775 & 31212 & 32212 & 33352 & 34533 & 36027 & 36625 & 29405 \\
Marlborough & 25747 & 26712 & 27475 & 28660 & 29657 & 30559 & 31625 & 32223 & 26329 \\
West Coast & 11436 & 11871 & 12221 & 12468 & 12977 & 13534 & 14147 & 14628 & 11789 \\
Canterbury & 20703 & 21127 & 21673 & 22080 & 22309 & 22697 & 23014 & 22993 & 20785 \\
Otago & 29706 & 30094 & 30026 & 30987 & 31709 & 32788 & 33478 & 34078 & 29526 \\
Southland & 27278 & 27890 & 28091 & 28364 & 29066 & 30059 & 31102 & 31810 & 27159 \\
Average & 30880 & 31573 & 32229 & 32938 & 33628 & 34282 & 34981 & 35529 & 31064 \\
\hline
\end{tabular}


Figure 6: Stumpage Profit Map for 2013 for All Planted Forest ( $\$ /$ ha)

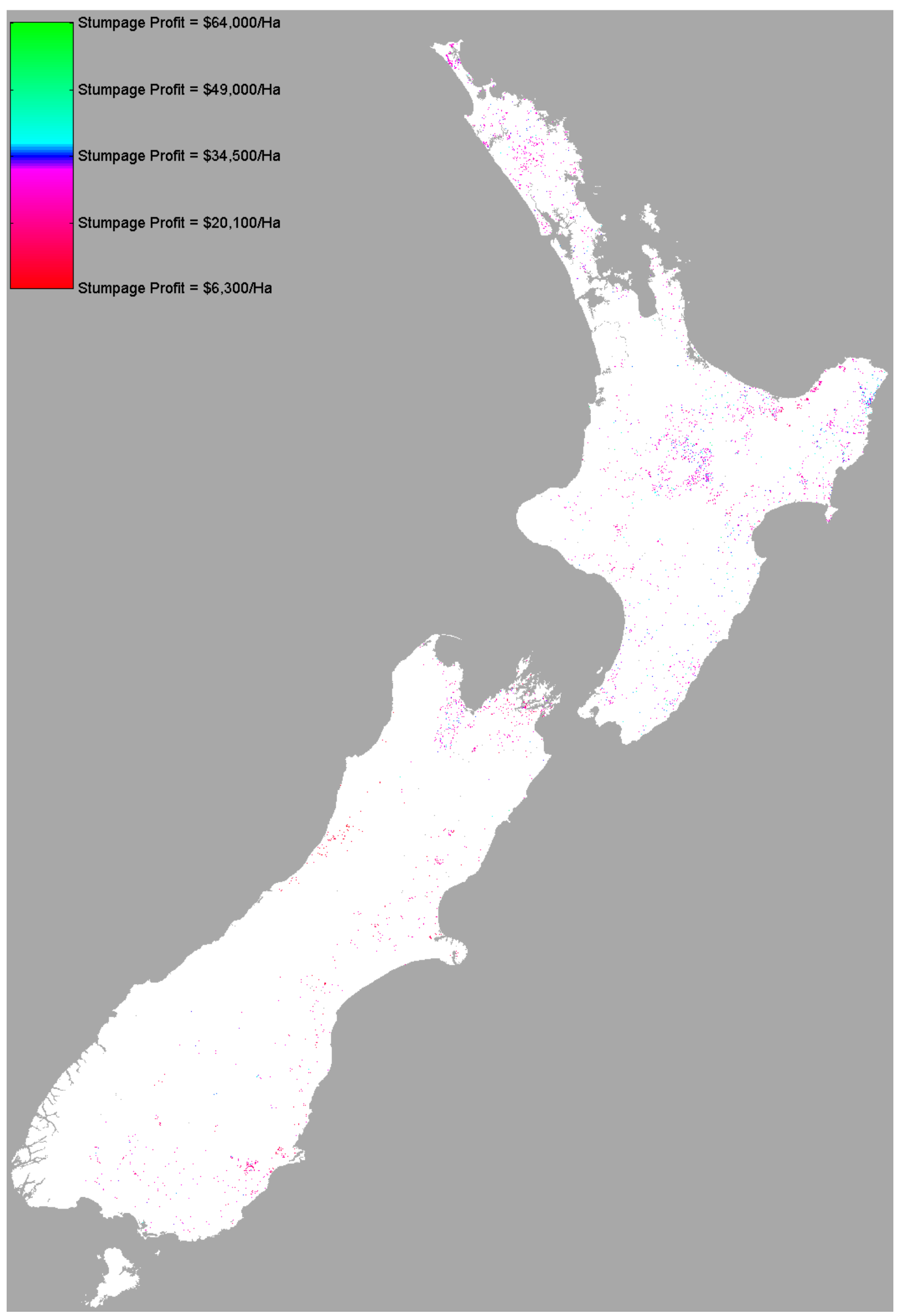


Figure 7: Stumpage Profit Map for 2030 for All Planted Forest ( $\$ /$ ha)

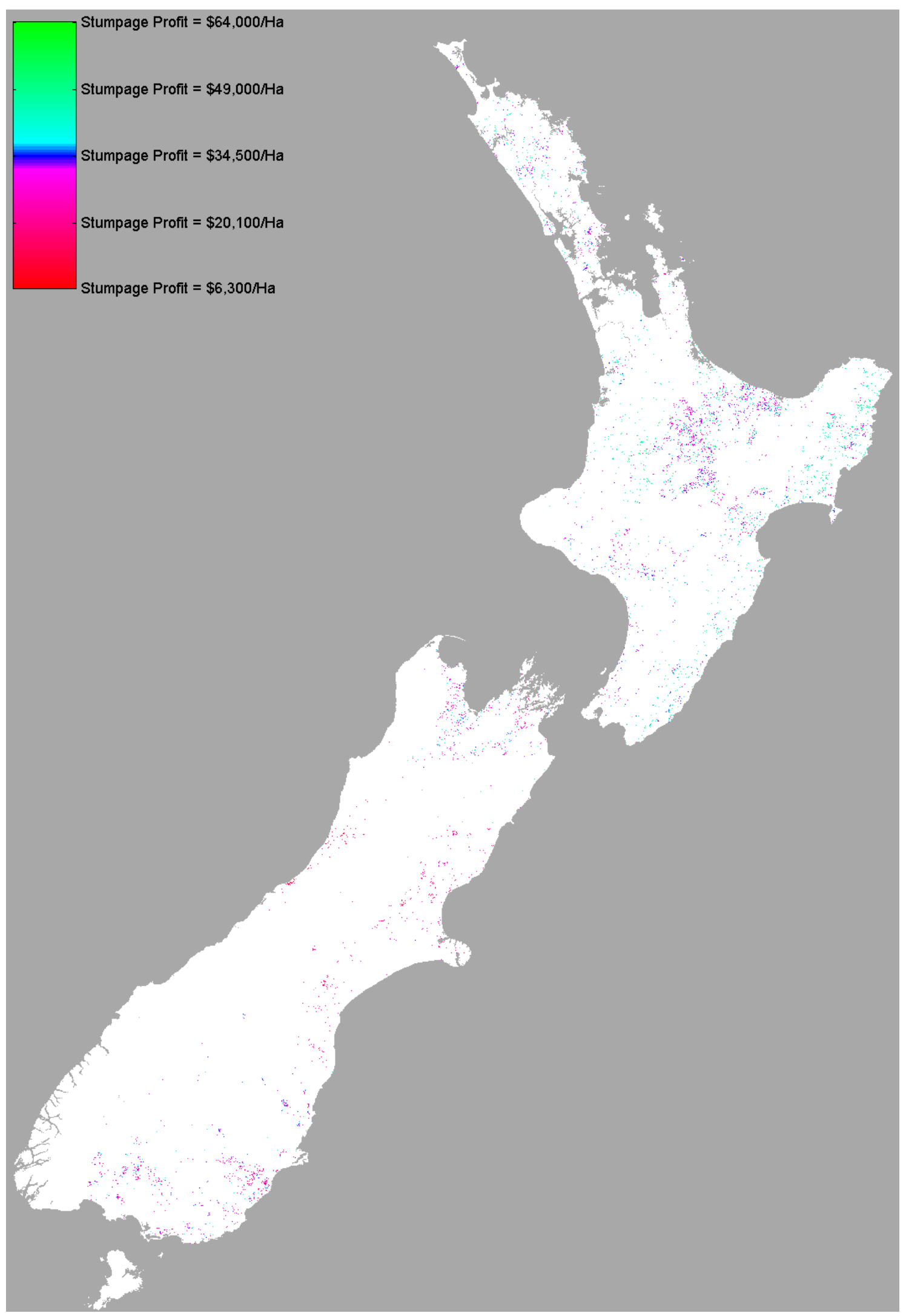


Figure 8: Average Stumpage Profit over 2013-2030 by Wood Supply Region by Forest Type

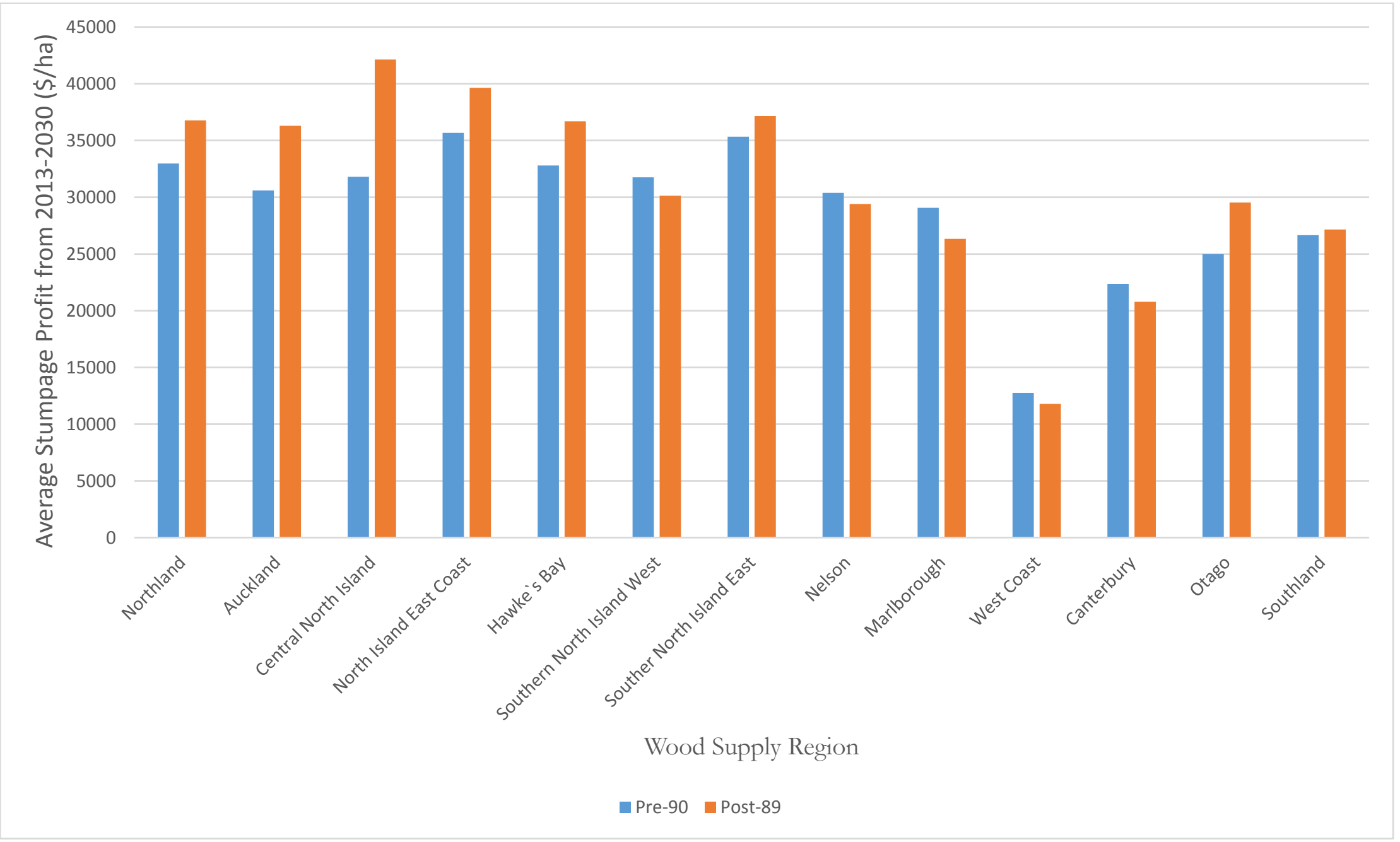


Figure 9: Average Stumpage Profit over Wood Supply Region by Year by Forest Type

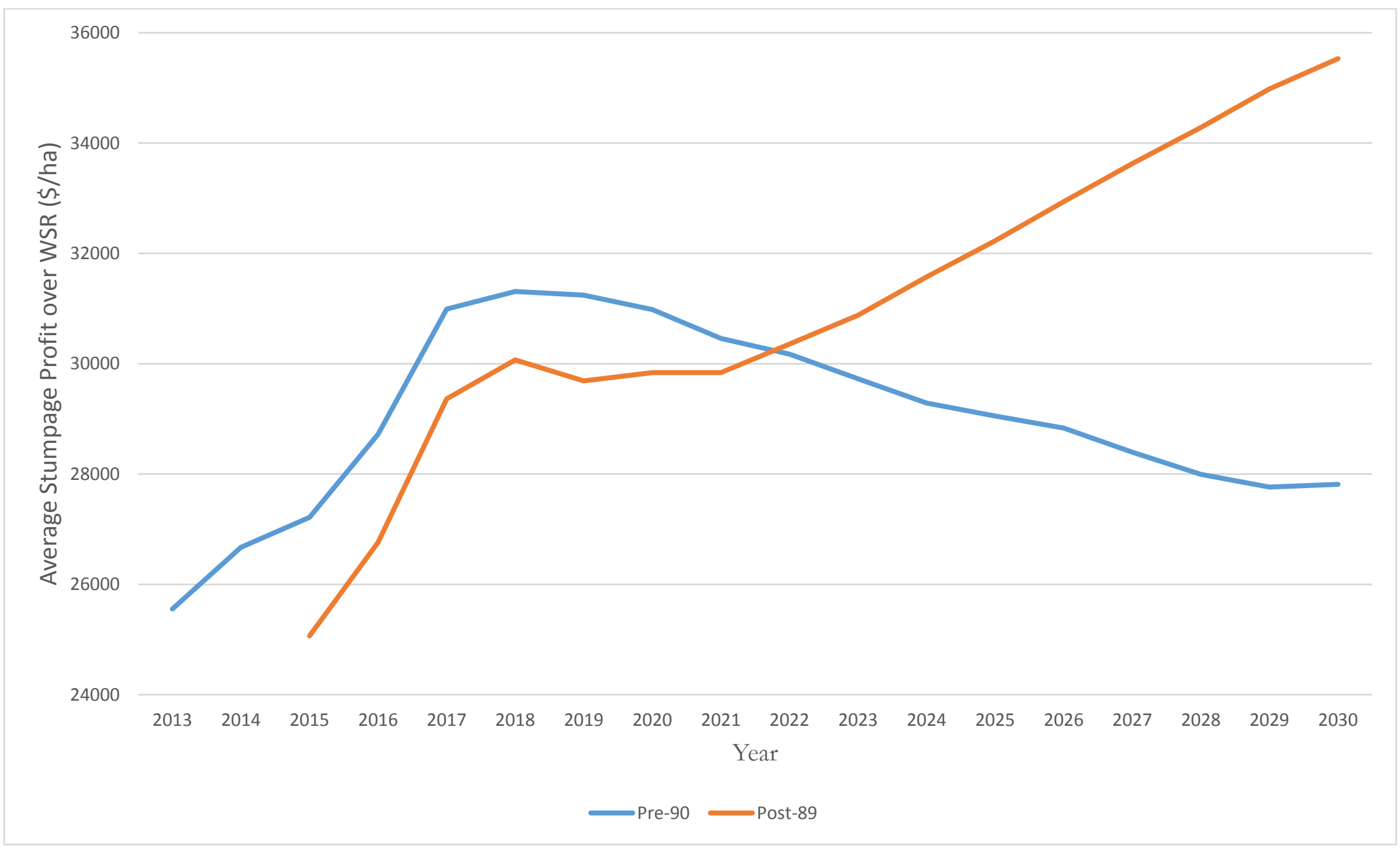


Figure 10: Histogram of Stumpage Profit for 2030 for Pre-90 Forest

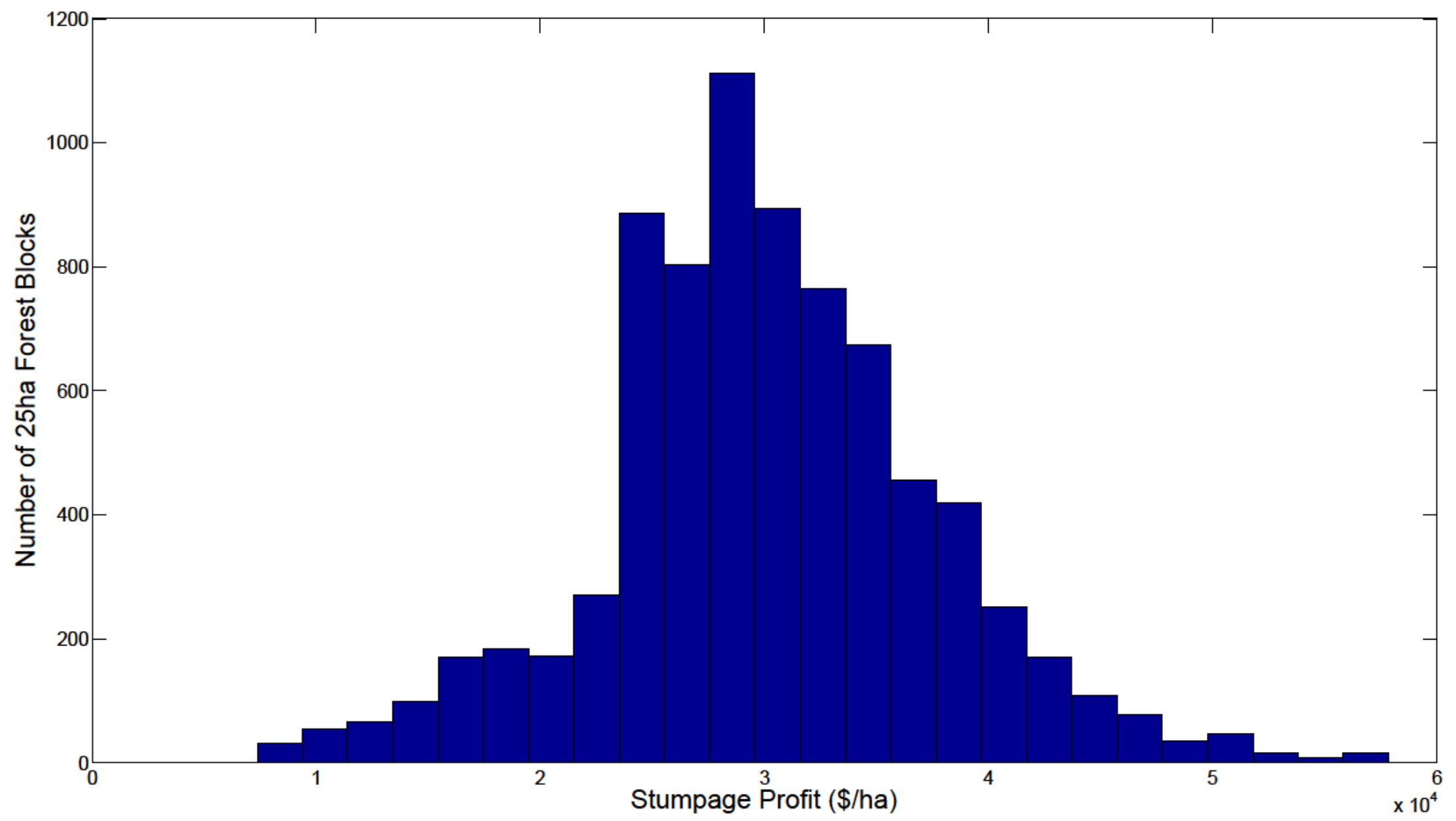


Figure 11: Histogram of Stumpage Profit for 2030 for Post-89 Forest

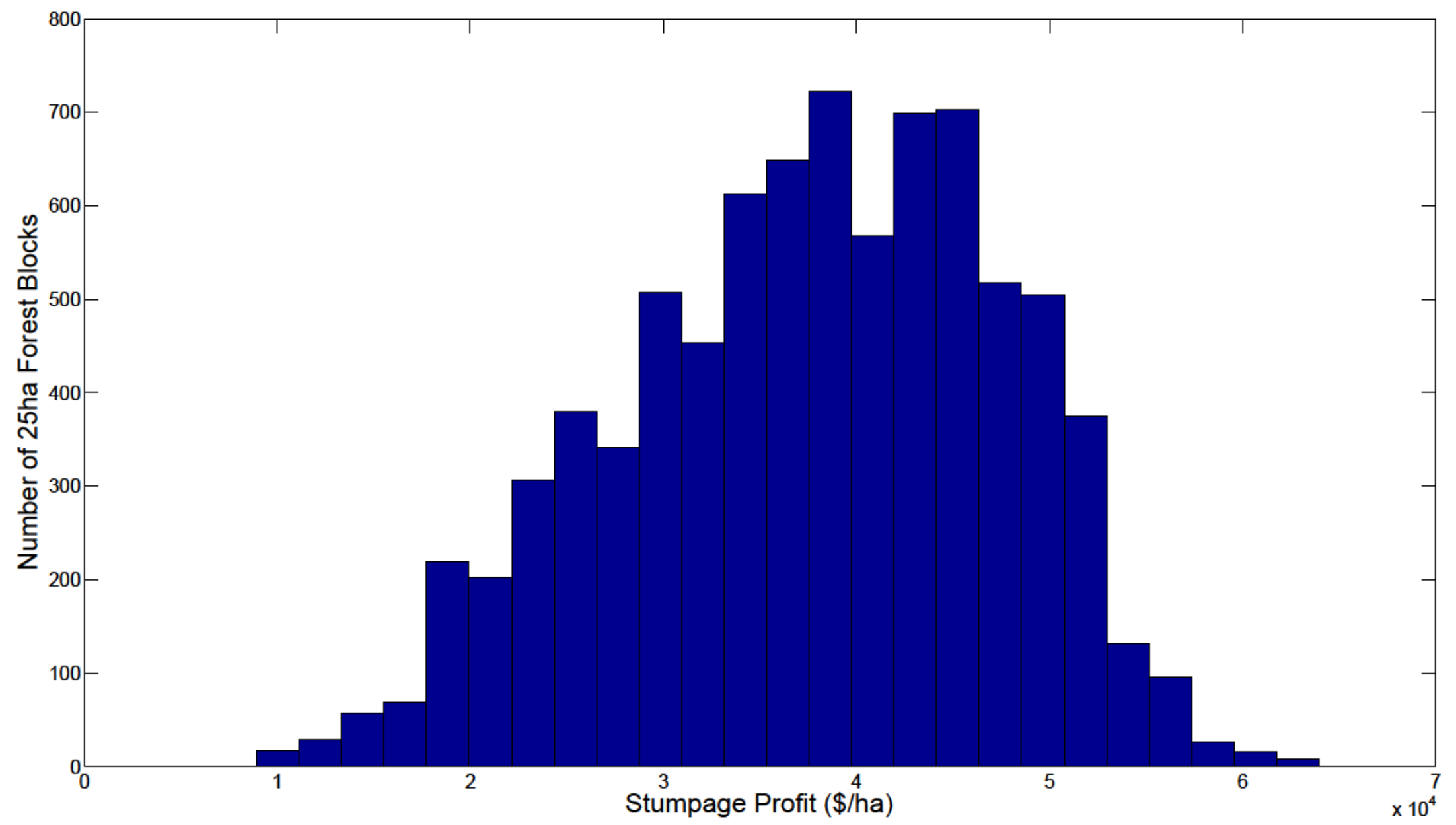


Figure 12: Stumpage Profit Map for 2030 for Pre-90 Forest $(\$ / \mathrm{ha})$

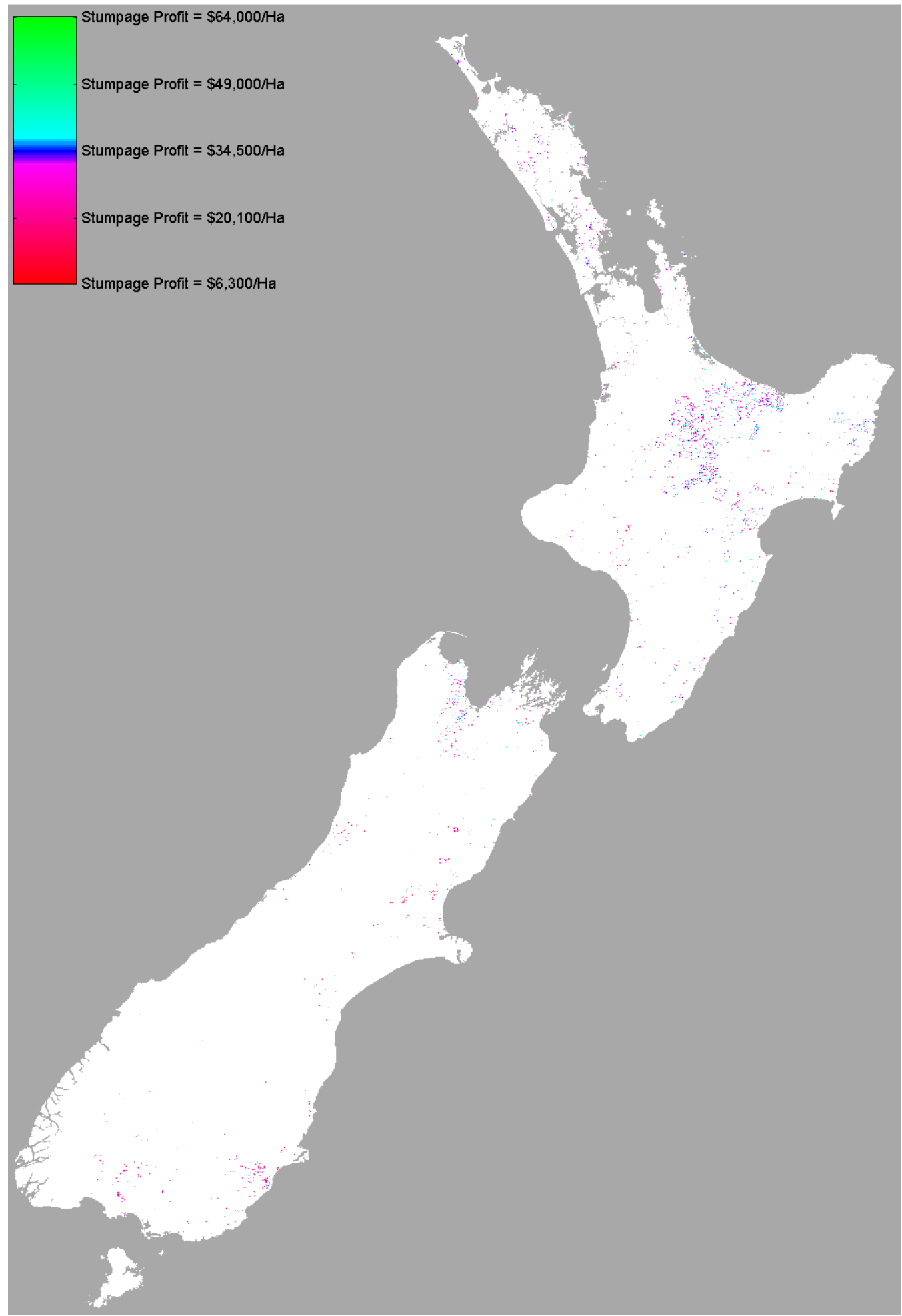


Figure 13: Stumpage Profit Map for 2030 for Post-89 Forest (\$/ha)

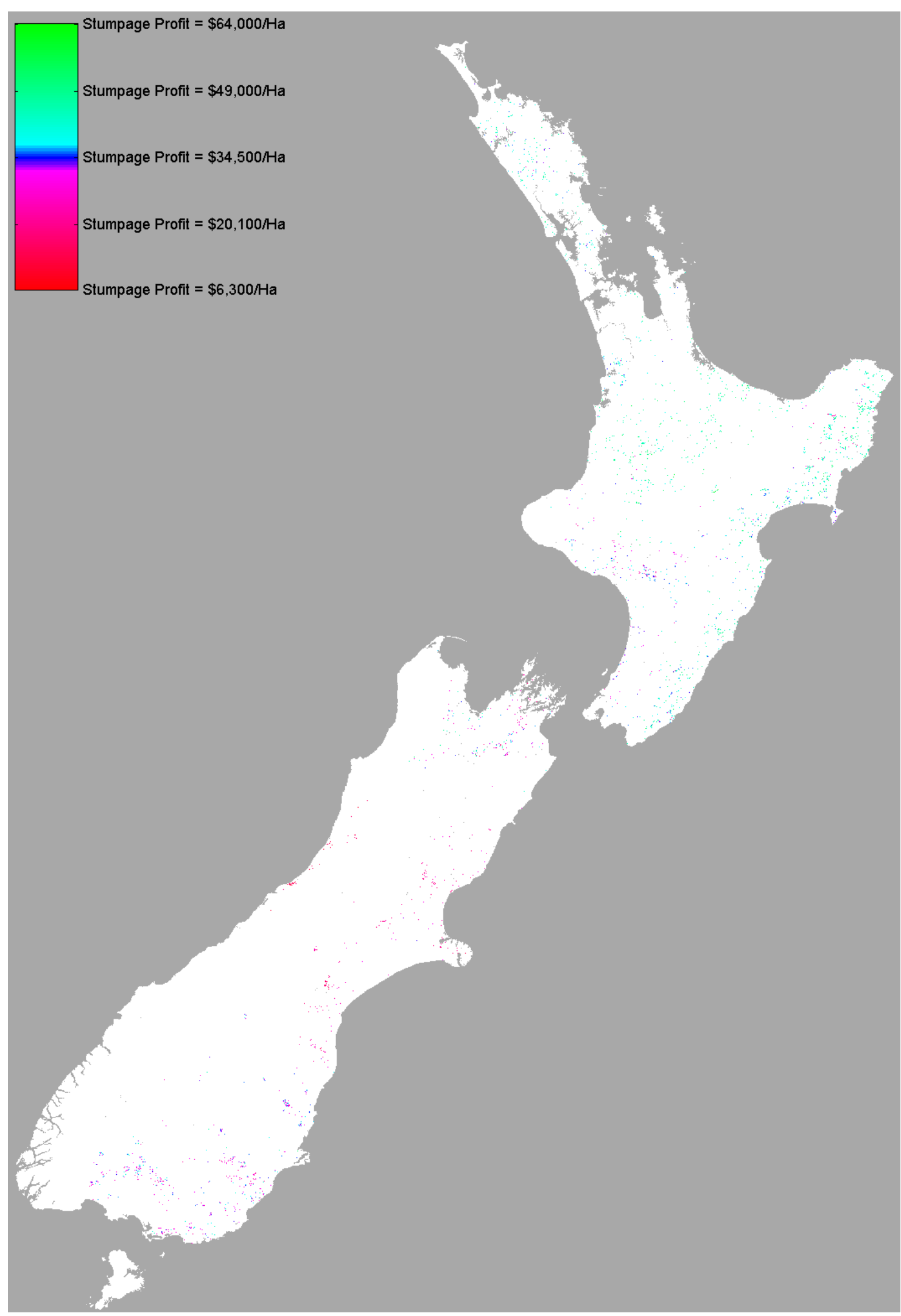


Figure 14: NPV Map for 2013 Pre-90 Forest ( $\$ /$ ha $)$ - 7\% discount rate

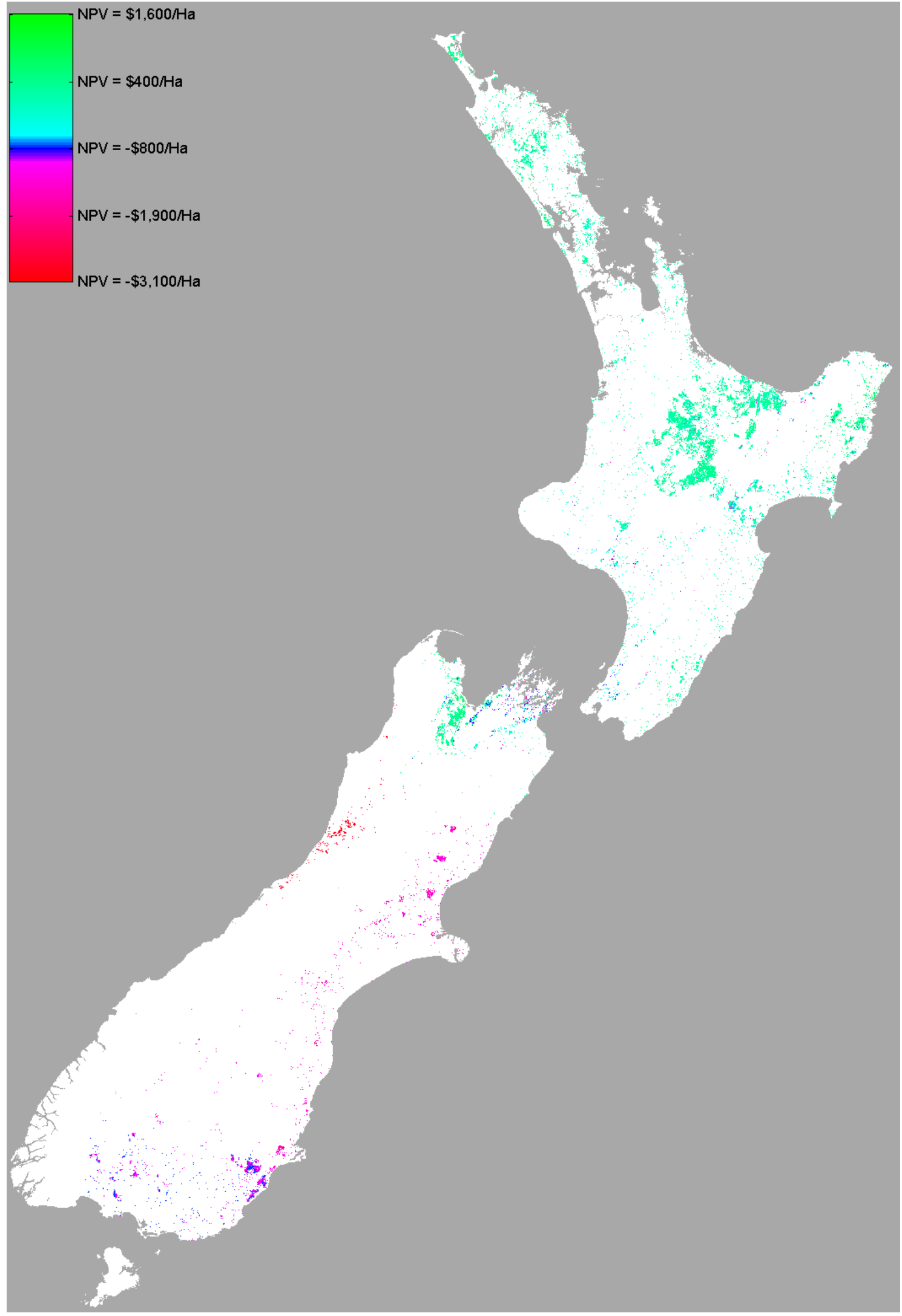


Figure 15: NPV Map for 2013 Post-89 Forest ( $\$ / \mathrm{ha})-7 \%$ discount rate

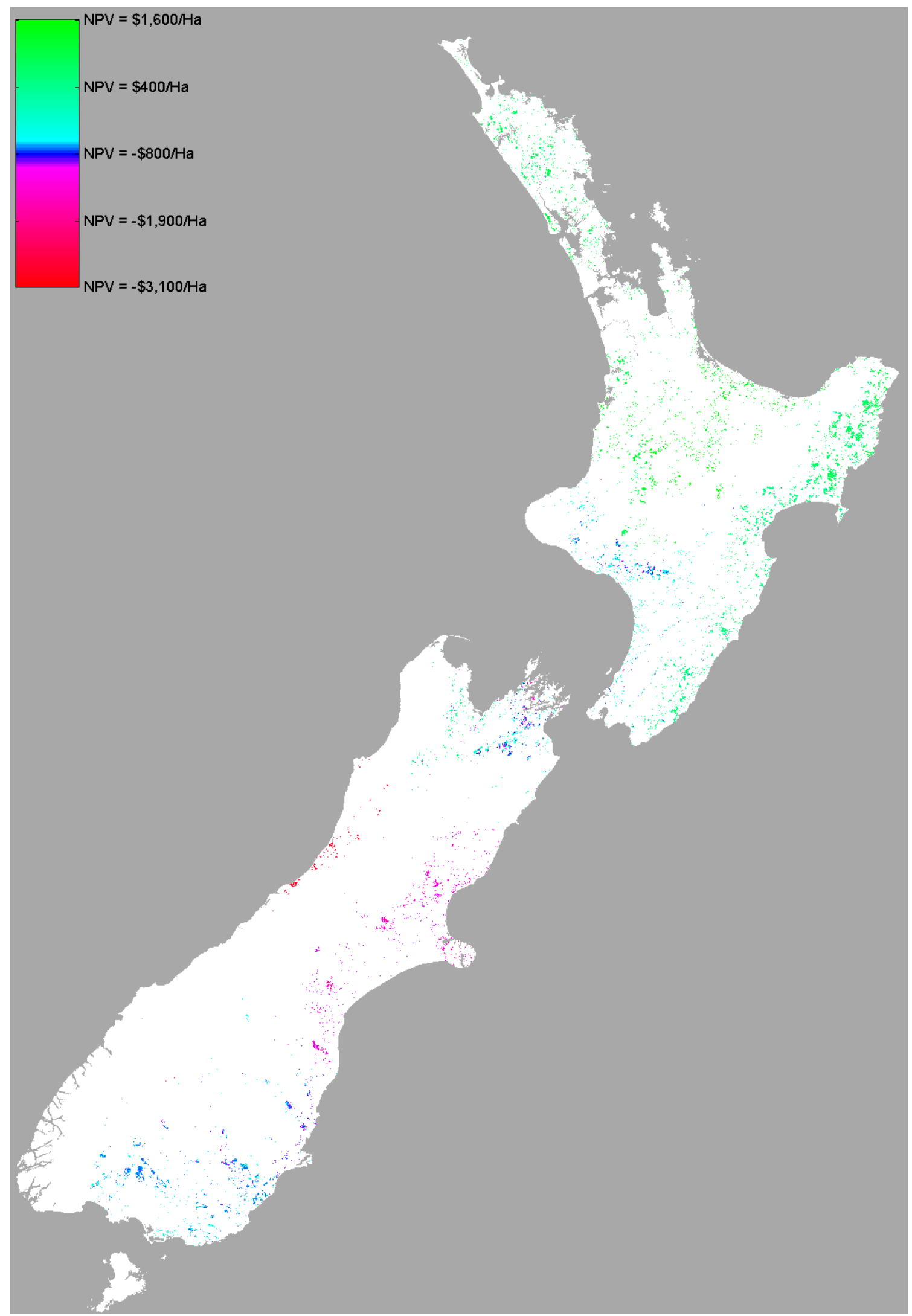


Figure 16: IRR Map for 2013 Pre-90 Forest (\$/ha)

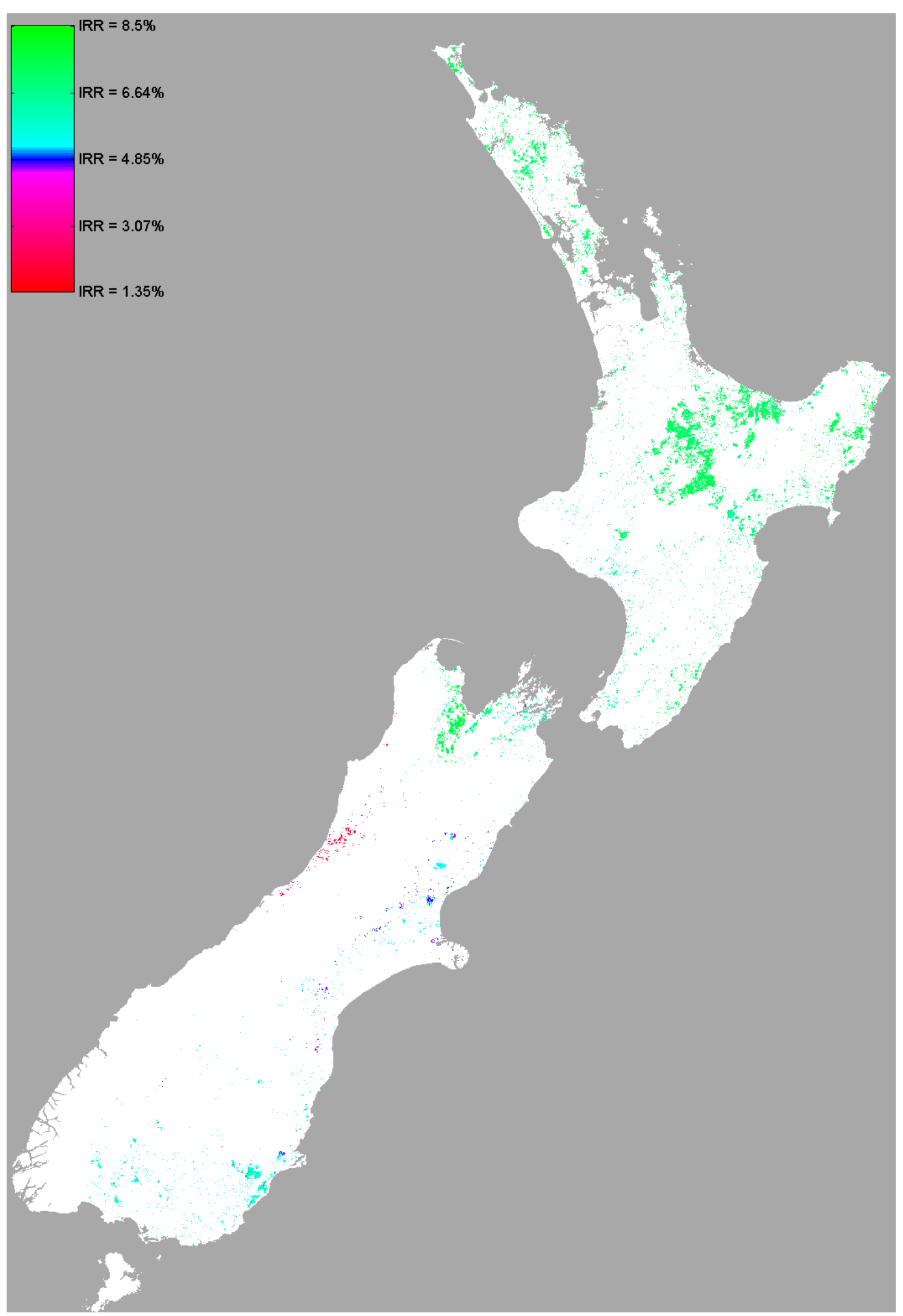


Figure 17: IRR Map for 2013 Post-89 Forest ( $\$ /$ ha)

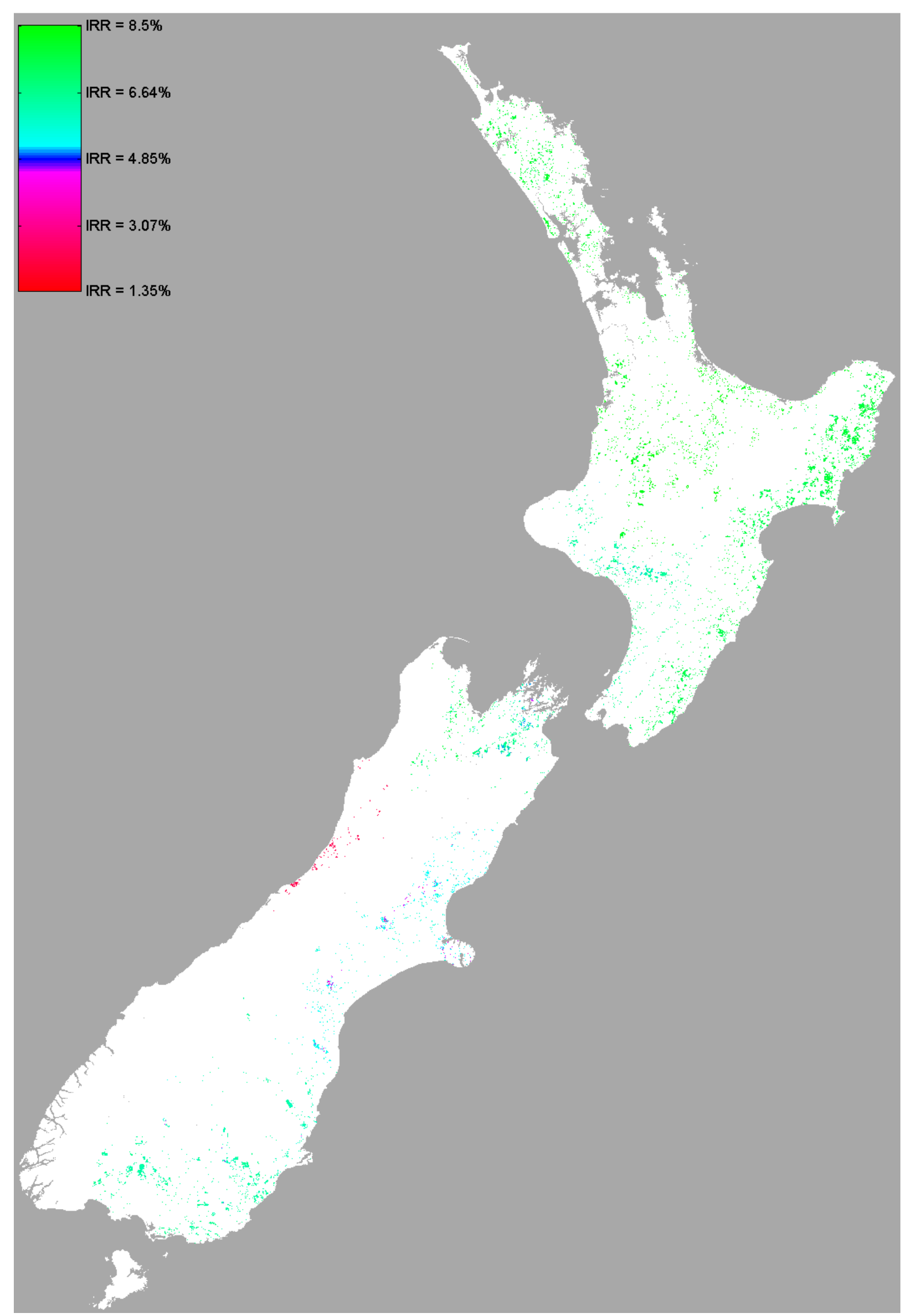




\section{Recent Motu Working Papers}

All papers in the Motu Working Paper Series are available on our website www.motu.org.nz, or by contacting us on info@motu.org.nz or +64 49394250.

15-16 Maré, David C, Dean Hyslop and Richard Fabling. 2015. "Firm Productivity Growth and Skill." (forthcoming)

15-15 Fabling, Richard and David C. Maré. 2015. "Production function estimation using New Zealand's Longitudinal Business Database."

15-14 Grimes, Arthur, Robert MacCulloch and Fraser McKay. 2015. "Indigenous Belief in a Just World: New Zealand Maori and other Ethnicities Compared."

15-13 Apatov, Eyal, Richard Fabling, Adam Jaffe, Michele Morris and Matt Thirkettle. 2015. "Agricultural Productivity in New Zealand: First estimates from the Longitudinal Business Database."

15-12:Laws, Athene, Jason Gush, Victoria Larsen and Adam B Jaffe. 2015. "The effect of public funding on research output: The New Zealand Marsden Fund." (forthcoming)

15-11 Dorner, Zachary and Suzi Kerr. 2015. "Methane and Metrics: From global climate policy to the NZ farm."

15-10 Grimes, Arthur and Marc Reinhardt. 2015. "Relative Income and Subjective Wellbeing: Intra-national and Inter-national Comparisons by Settlement and Country Type"

15-09 Grimes, Arthur and Sean Hyland. 2015. "A New Cross-Country Measure of Material Wellbeing and Inequality: Methodology, Construction and Results."

15-08 Jaffe, Adam and Trinh Le. 2015. "The impact of R\&D subsidy of innovation: a study of New Zealand firms."

15-07 Duhon, Madeline, Hugh McDonald and Suzi Kerr. 2015 "Nitrogen Trading in Lake Taupo: An Analysis and Evaluation of an Innovative Water Management Policy.

15-06 Allan, Corey, Suzi Kerr and Campbell Will. 2015. "Are we turning a brighter shade of green? The relationship between household characteristics and greenhouse gas emissions from consumption in New Zealand" (forthcoming)

15-05 Fabling, Richard and Lynda Sanderson. 2015. "Exchange rate fluctuations and the margins of exports"

15-04 Fabling, Richard, Richard Kneller and Lynda Sanderson. 2015. "The impact of tax changes on the shortrun investment behaviour of New Zealand firms"

15-03 Sin, Isabelle, Steven Stillman. 2015. "Economic Liberalisation and the Mobility of Minority Groups: Evidence for Māori in New Zealand"

15-02 Grimes, Arthur, Ian Mitchell. 2015. "Impacts of Planning Rules, Regulations, Uncertainty and Delay on Residential Property Development"

15-01 De Rassenfosse, Gaétan, and Adam B. Jaffe. 2015. “Are Patent Fees Effective at Weeding Out LowQuality Patents?"

14-15 Sin, Isabelle, Richard Fabling, Adam Jaffe, David C. Maré and Lynda Sanderson. 2014. "Exporting, Innovation and the Role of Immigrants."

14-14 McLeod, Keith, Richard Fabling and David C. Maré. 2014. "Hiring New Ideas: International Migration and Firm Innovation in New Zealand." 